\title{
How Do Informal Social Networks Impact on Labor Earnings in Turkey? ${ }^{1}$
}

Bengi YANIK-ILHAN (https://orcid.org/0000-0003-1578-8390), Department of Economics, Altınbaş University, Turkey; e-mail: bengi.ilhan@altinbas.edu.tr

Ayşe Aylin BAYAR (https://orcid.org/0000-0003-2319-6491), Department of Management Engineering, Istanbul Technical University, Turkey; e-mail: bayaray@itu.edu.tr

Nebile KORUCU-GÜMÜŞÖ̆LU (https://orcid.org/0000-0003-3308-4362), Department of International Trade, Istanbul Kültür University, Turkey; e-mail: n.gumusoglu@iku.edu.tr

\section{Türkiye'de Enformel Sosyal Çevre İşgücü Kazançlarına Nasıl Etkide Bulunmaktadır?²}

\begin{abstract}
The informal social networks are one of the prominent factors in the labor market decisions both for the supply and demand side. Particularly, in developing countries, like Turkey, these informal networks have an influence on the labor market. However, even the existence of this issue, the impact of informal social networks has not been argued sufficiently for the Turkish case. In this respect, this study advances existing researches, by implementing the quantile regression method to reveal the impact of the informal social networks. The quantile regression analysis reveals the impacts of the different quantiles of wages. The Household Labor Force Survey (HLFS) is utilized for 2004-2016 period. The findings indicate that being recruited by social contacts has negative impact on wage levels and in consequence, aggregate productivity is decreased from low quality of labor force and the low return to the firm.
\end{abstract}

Keywords $\quad$ : Informal Networks, Quantile Regression, Employment, Turkey.

JEL Classification Codes : J00, J21, J30.

\section{$\ddot{\mathbf{O} z}$}

Enformel sosyal çevre, hem talep hem de arz yönlü emek piyasası kararları ile ilgili etkili olan belirgin faktörlerden biridir. Özellikle Türkiye gibi gelişmekte olan ülkelerde, enformel sosyal çevrenin emek piyasası üzerinde etkisi söz konusudur. Fakat, bu konunun önemine rağmen, Türkiye

1 This article is the revised and extended version of the paper presented in ICOMEP-18-Spring, "International Congress of Management, Economy and Policy" held on April 28-29, 2018 in Istanbul/Turkey and "Third International Annual Meeting of Sosyoekonomi Society” which was held by Sosyoekonomi Society and CMEE - Center for Market Economics and Entrepreneurship of Hacettepe University and, Faculty of Economics and Administrative Sciences of Hacettepe University, in Ankara/Turkey, on April 28-29, 2017.

2 Bu makale 28-29 Nisan 2018 tarihlerinde Istanbul'da düzenlenen "ICOMEP-18-Bahar, Uluslararası Yönetim, Ekonomi ve Politika Kongresi"nde ve Sosyoekonomi Derneği ile Hacettepe Üniversitesi Piyasa Ekonomisini ve Girişimciliği Gelişstirme Merkezi ve Hacettepe Üniversitesi Íktisadi ve İdari Bilimler Fakültesi tarafindan Türkiye'nin Ankara şehrinde, 28-29 Nisan 2017 tarihlerinde düzenlenen "Üçüncü Uluslararası Sosyoekonomi Derneği Yıllık Buluşması ”nda sunulan çalışmanın gözden geçirilmiş ve genişletilmiş halidir. 
özelinde enformel sosyal çevrenin etkileri ile ilgili yeteri boyutta tartışma literatürde yer almamaktadır. bu bağlamda, literatürde yer alan bu boşluğu doldurabilmek için, bu çalışmada, enformel sosyal çevrenin etkilerinin tahmin edilebilmesi için kantil regresyon analizi uygulanmıştır. Kantil regresyon analizi farklı kantilerdeki etkilerin açığa çıkarılmasını sağlamaktadır. 2004-2016 dönemine ait Hanehalkı İşgücü Anketleri kullanılmıştır. Elde edilen bulgulara göre, enformel sosyal çevre aracılığıyla iş bulmanın ücret düzeyi üzerinde negatif etkisi söz konusudur. Bununla birlikte, işgücü kalitesinin ve firma getirisinin düşüklügünün toplam üretkenliği azalttığına dair sonuçlar elde edilmiştir.

Anahtar Sözcükler $\quad$ : Enformel Sosyal Çevre, Kantil Regresyon İstihdam, Türkiye.

\section{Intoduction}

There exist different ways of job recruitment for job seekers and firms. These ways are widely discussed in the various studies in the literature. Depending on the cultural background and labor market dynamics, the most known way is to apply directly to the employer. The other ways of applying for a job are to insert or answer adverts in websites, newspapers, employment or vocational guidance agencies. In addition to these, the informal social networks such as family, friends, relatives or other contacts, are extensively preferred by both the individuals and the firms, as well. In this context, as the ratio of informal social network among the other ways cannot be negligible, a significant number of studies in the literature point out on this matter. According to them, the informal methods or personal contacts are chosen for application of job vacancies (Hölzer, 1987; Silliker, 1993; Elliot, 1999). Though, no consensus is provided on the direction and magnitude of impact of the informal social networks on searching job and wage levels.

Some studies in which the causality between social networks and wage levels indicate that the asymmetric information is lowered by informal contract due to low uncertainty about the match of the quality of the job. According to these studies, informal social contact provides a proper channel for information transmission, therefore, the better matches' leads to a higher level of wages (Montgomery, 1991; Dustman et al., 2016). In another study, it is hypothesized that the quality of social networks is positively correlated with the productivity of prospective workers (Montgomery, 1991). It is believed that high ability workers are mostly known by the same ability workers. In that sense, to find the most suitable workers, employers hired individuals who has referrals as they treat the employee's referrals as a positive signal for the employee's skills and abilities. In addition to that, because they treat employee's referrals as positive signal of skills and abilities, firms pay higher wages to the referred workers because they thought those ones are high ability workers (Pistaferri, 1999). From this point of view, it can be said that using network channels during job search improve labor market outcomes among the workers such as increasing the probability of finding job or increasing the wage offers etc (Munshi, 2003). Even tough, theoretical expectations suggest social networks create better conditions and matches for the workers Some empirical studies in the literature put some controversial results about the specific issue (Montgomery, 1991; Simon \& Warner, 1992; Casella \& Hanaki, 2006, 2008; Beaman \& Magruder, 2012; Dustmann et al., 2011; Brown et al., 2012). 
Yanık-İlhan, B. \& A.A. Bayar \& N. Korucu-Gümüşoğlu (2019), "How Do Informal Social

Networks Impact on Labor Earnings in Turkey?", Sosyoekonomi, Vol. 27(41), 183-210.

In addition, the same evidence is concluded from another study, as well. Hensvik and Skans (2013) show that higher entry wage levels are obtained by workers who have linkage with an existing employee. The wage premium rises depending on the abilities of the linked incumbent worker. The results prove that workers with low ability social networks will accounted as low productivity. These workers mostly prefer to find job through formal channels. In this respect, the usage of network channels creates inequality in wages and the social conditions of individual may have an influence on distribution of wages.

Some studies suggest that in order to maintain their reputation, workers are more prefer to be a reference only to good applicants (Saloner, 1985; Montgomery, 1991; Kugler; 2003). In this respect, applicants with low abilities less likely to be referred to a job by workers. Moreover, there is another reason is the fact that referees monitor the refereed worker. Thus being monitored make workers productive. Studies mostly explore a positive relation between wage level and finding a job with referral (Marmaros \& Sacerdote, 2002; Brown et al., 2016; Dustman et al., 2016).

On the contrary, other studies point out that find a suitable job by using referral creates a decrease or no effect on wage levels (Franzen \& Hangartner, 2006; Bentolila et al., 2010). While for some of the European countries such as Belgium, Australia and the Netherlands, find a job through a referral induces an increase in the wage levels, some other countries such Italy, Portugal, Greece and United Kingdom, the opposite impact arise (Bentolila et al., 2010). In addition, Pellizzari (2004) found that there is no effect for the other European countries and United States. Torres and Huffman (2002) provides a little evidence about the fact that network channels cause higher wage levels than the other ways of finding job.

Besides, some other studies in which the causes of negative impact of finding a job with referral on wage levels are widely examined and one crucial reason is derived at the one study. Pellizzari (2004), concluded that, this negativity will arise from the strategies of the firm during the process of hiring.

There is another reason for the negative impact of finding the job on wages because personal contacts are usually maintained for the purposes that are not related the job (Bentolila et al., 2010). Besides, for specific occupations and/or labor market segments, there is an opportunity for unemployed person to find a job through a referral. Therefore, the abilities of the persons cannot fully meet. In other words, this kind of personal contacts may create a discrepancy between occupational choices and comparative advantage of production of workers. According to Pistaferri (1999), the reasons of the negative impact of informal network on wage levels can aggregated into two. One of the reason is about the informal network channels which are proxies for job characteristics that are not observed. For instance, as in Italy there exist no regulation about hiring process and wage setting, the firm size cannot observe for small firms. In that sense, finding a suitable job by using social contacts embodied the linkage between the size of firm and incomes. The second reason of the negative impact of informal network is because of unobserved low skills and abilities. as these are closely related to searching for job through network, it plays a crucial role. 
The effect of gender differences for the usage of social network channels during the job search are also mentioned in some of the studies (Brass, 1985; Beggs \& Hurlbert, 1997; Campbell, 1988; Ibarra, 1992; Huffman \& Torres, 2001; Straits, 1998). Some of them focuses on to reveal whether use of different methods of searching job for male and female are differ or not. Besides, they also try to answer whether the differences in the search methods point out to differentiation at employment outcomes or not. These studies concluded that the there exists a gender differential for employment outcomes including occupational segregation and incomes. This conclusion mainly arises as a result of differences of women and men's social relations while the network of men is mainly related with the work relations, for women's, these network channels mostly rely on kin (Moore, 1990). In that sense, women are relatively more disadvantage compared to men for searching job through personal contacts (Drentea, 1998).

Moreover, the impact of social networks on the labor market situation is also examined in some other studies. According to the findings, the duration of unemployment is effected from social networks. Depending on the increase in the share of currently employed contacts, the duration of unemployment of individual decreases (Akerlof, 1980; Bramoullé \& Saint-Paul, 2010; Bentolila et al, 2010; Akerlof \& Kranton, 2000).

Social network channels also impact the migrants' labor market outcomes. Greater network of the migrant will accelerate to find a job and also induce a higher wage level (Beaman, 2011; Goel \& Lang, 2009; Giulietti et al, 2010). Besides, in one study the degree of the impact of local interaction on native and non-native workers is investigated and it is stressed that, the degree for non-native workers is nearly twice strong as for native ones. The results show a similar pattern for young workers, and opposite pattern for olders (Schmutte, 2015).

According to our knowledge, the impact of different ways of searching a job to find a suitable one has not been questioned for the Turkish case. Therefore, the present paper target to fulfil the gap of this issue in the literature. Contrast to other studies in the literature, which mainly employ mean regression (OLS) to reveal the impact of crucial variables on wage, a more informative approach, quantile regression, is chosen. The choice criterion relies on the fact that insufficiency of the OLS regression. This method only explores the impact of variables at the mean of the distribution, however in fact, the impact of the variables on wage distribution differ along with the whole distribution. Therefore, this approach will lead to inadequate results. In this respect, as the quantile regression allows to estimate the impact of the variables on specific different quantile of wage distribution, this approach will reveal more comprehensive results (Koenker \& Basset, 1978). Household Labor Force Survey (HLFS) data for the period of 2004-2016 is employed. It is limited to only wage workers who are older than 15 years old. For the empirical investigation, the natural logarithm of wage is chosen for as a dependent variable and human capital endowments such as education, age, previous labor market status and also living area such as region, and the answers for the question "How did you find this job" are taken as independent variables. 
This paper consists of five sections. After the introduction section, the second section contains data and methodology part. The third section includes the different ways of finding a current job in Turkey. Empirical results are represented in the fourth section and finally, the conclusion is last section.

\section{Data and Methodology}

\subsection{Data}

In the present paper, the empirical analysis is implemented by utilizing the Household Labor Force Survey (HLFS) stem from the TurkStat for the period of 2004-2016. Corresponding to main aim of the paper, only wage workers who are older than 15 years old and the individuals who start working their current jobs within two years are chosen. The ones who were in school, military, inactive and unemployed previous year and whose $\ln$ (income) is greater than 1. The quantile regression technique is applied for the investigation as this methodology has some advantages for the distributions such as wage and income ${ }^{3}$. In that sense, the dependent variable is the natural logarithm of wage whereas characteristics of individuals' such as age, education, previous labor market status and living area, the answers for the question "How did you find this job" are the independent variables. As to adjust the price effect on the incomes, the nominal incomes of individual's are converted to real. For this purpose, CPI in terms of 2016 prices are used.

The descriptive analysis results are represented in Table 1 . The total sample includes 147220 individuals. Among them, 2082 individuals did not answer the ways of finding the job, in that sense, the number of the sample is decreased to 145138. According to analysis results, the mean of the real wage is $521 \mathrm{TL}$ and the minimum and maximum value of the real wages are $1.43 \mathrm{TL}$ and $12628 \mathrm{TL}$, respectively.

More than half of the sample is males (0.66). According to the education level of individuals, it can be seen that more than half of the sample has a lower education level than higher education. The percentage of primary educated individuals and the percentage of secondary school graduates are nearly 0.26 . High school and vocational school percentage have the same level $(0.12)$ while the ratio of university and higher school graduates is nearly 0.17 .

The results of the previous labor market situation point out that most of the individuals were unemployed (53\%). Individuals who were in school in previous years is $18 \%$ of the sample while the ones who were inactive is $19 \%$. The lowest percentage belongs to the ones in the military, which is around $1 \%$. When the ways of finding a job are examined, it can be observed that the highest percentage belongs to "network" which is around $31 \%$. 
Table: 1

Summary of Descriptive Analysis

\begin{tabular}{|c|c|c|c|c|c|}
\hline Variables & Observ. & Mean & St. Dev. & Min & Max \\
\hline $\begin{array}{l}\text { Dependent Variable } \\
\text { Ln Real Wage }\end{array}$ & 147220 & 521.9 & 479.4 & 1.4 & 12628.2 \\
\hline \multicolumn{6}{|c|}{ Individual Characteristics } \\
\hline $\begin{array}{l}\text { Male } \\
\text { Age } \\
\text { Literate } \\
\text { Primary } \\
\text { Secondary } \\
\text { General High School } \\
\text { Vocational High School } \\
\text { University and Higher }\end{array}$ & $\begin{array}{l}147220 \\
147220 \\
147220 \\
147220 \\
147220 \\
147220 \\
147220 \\
147220\end{array}$ & $\begin{array}{c}0.7 \\
28.8 \\
0.04 \\
0.26 \\
0.27 \\
0.1 \\
0.1 \\
0.2\end{array}$ & $\begin{array}{c}0.5 \\
10.9 \\
0.2 \\
0.4 \\
0.4 \\
0.3 \\
0.3 \\
0.40\end{array}$ & $\begin{array}{c}0.0 \\
15.0 \\
0.0 \\
0.0 \\
0.0 \\
0.0 \\
0.0 \\
0.0\end{array}$ & $\begin{array}{c}1.0 \\
65.0 \\
1.0 \\
1.0 \\
1.0 \\
1.0 \\
1.0 \\
1.0\end{array}$ \\
\hline $\begin{array}{l}\text { Unemployment (t-1) } \\
\text { Military (t-1) } \\
\text { In school (t-1) } \\
\text { Inactive (t-1) }\end{array}$ & $\begin{array}{c}\text { Previous L } \\
147220 \\
147220 \\
147220 \\
147220\end{array}$ & $\begin{array}{l}\text { ket State } \\
0.53 \\
0.09 \\
0.20 \\
0.19\end{array}$ & $\begin{array}{l}0.50 \\
0.30 \\
0.40 \\
0.40\end{array}$ & $\begin{array}{l}0.0 \\
0.0 \\
0.0 \\
0.0\end{array}$ & $\begin{array}{l}1.0 \\
1.0 \\
1.0 \\
1.0\end{array}$ \\
\hline $\begin{array}{l}\text { By own } \\
\text { Private Office } \\
\text { Public Office } \\
\text { Network } \\
\text { Other }\end{array}$ & $\begin{array}{c}\text { Ways of } \boldsymbol{F i} \\
145138 \\
145138 \\
145138 \\
145138 \\
145138\end{array}$ & $\begin{array}{c}\text { rent Job } \\
0.65 \\
0.003 \\
0.02 \\
0.31 \\
0.01\end{array}$ & $\begin{array}{l}0.476 \\
0.054 \\
0.139 \\
0.462 \\
0.116\end{array}$ & $\begin{array}{l}0.0 \\
0.0 \\
0.0 \\
0.0 \\
0.0\end{array}$ & $\begin{array}{l}1.0 \\
1.0 \\
1.0 \\
1.0 \\
1.0\end{array}$ \\
\hline \multicolumn{6}{|c|}{ Years } \\
\hline 2004 & 147220 & 0.06 & 0.228 & 0.0 & 1.0 \\
\hline 2005 & 147220 & 0.06 & 0.246 & 0.0 & 1.0 \\
\hline 2006 & 147220 & 0.07 & 0.246 & 0.0 & 1.0 \\
\hline 2007 & 147220 & 0.07 & 0.248 & 0.0 & 1.0 \\
\hline 2008 & 147220 & 0.07 & 0.247 & 0.0 & 1.0 \\
\hline 2009 & 147220 & 0.07 & 0.254 & 0.0 & 1.0 \\
\hline 2010 & 147220 & 0.09 & 0.282 & 0.0 & 1.0 \\
\hline 2011 & 147220 & 0.09 & 0.292 & 0.0 & 1.0 \\
\hline 2012 & 147220 & 0.09 & 0.286 & 0.0 & 1.0 \\
\hline 2013 & 147220 & 0.09 & 0.283 & 0.0 & 1.0 \\
\hline 2014 & 147220 & 0.09 & 0.281 & 0.0 & 1.0 \\
\hline 2015 & 147220 & 0.09 & 0.285 & 0.0 & 1.0 \\
\hline 2016 & 147220 & 0.08 & 0.273 & 0.0 & 1.0 \\
\hline
\end{tabular}

\subsection{Methodology}

The studies that target to explain the impact of the different variables on the wage or income earnings mostly examine, the relation by using mean regression. However, as this regression relies estimation of ordinary least squares (OLS), there occur some limitations. OLS regression is valid only for the cases in which the effect of independent variables along the conditional distribution is unimportant. In that respect, as the OLS technique only reveals the impact of the different variables at the mean point of the distribution, it will be insufficient for the wage and/or earnings distributions. In fact, the impact of some variables on the conditional distribution of the dependent variable differ along with the whole distribution. Thus, ignoring that kind of a possibility may cause several serious weaknesses for the examination. 
As the present paper targets to reveal the impact of variables on wage distribution, instead of utilizing a regression model for averages ${ }^{4}$, more comprehensive method, the quantile regression method, is employed. The quantile regression method mostly preferred for the wage or earnings distributions, as it allows to make an estimation for specific quantiles of conditional wage distribution (Koenker \& Basset, 1978). Among other methods, the impact of independent variable on the different points of wage distribution is much more informative. As stated before, the impact of independent variables on the dependent variable differ along with the whole distribution, OLS method will be insufficient for the wage distribution as it may be different for the whole investigated period. In that respect, OLS method yields biased estimation results. In the present paper, in order to obtain the quantile wage regression equations by depending on some of the independent variables, the Mincer's (1974) human capital theory is followed ${ }^{5}$. The quantile regression model mainly focusses on several selected quantiles on the conditional wage distribution. For the estimation the least absolute deviation (LAD) estimator is used. The quantile wage regression model is identified as follows (Koenker \& Bassett, 1978; Buchinsky, 1994):

$$
\ln W_{i}=\beta_{\theta} x_{i}+u_{\theta i} \text { with Quantile }{ }_{\theta}\left(\ln W_{i} / x_{i}\right)=\beta_{\theta} x_{i}
$$

where $\mathrm{x}_{\mathrm{i}}$ represents independent variables vector, $\beta_{\theta}$ is parameter vector, and $\ln W_{i}$ is the natural logarithm of wages (including payment of wages, social payments and bonuses), at last $u_{\theta i}$, is random disturbance term. The basic characteristics of individuals such as age, education, region and previous labor market status and the answers for the question "How did you find this job" is included to the model as independent variables. Quantile $_{\theta}\left(\ln W_{i} / x_{i}\right)$ denotes the $\theta$ th conditional quantile of logarithmic wage on $x_{i}$. Note that, the coefficients will differ depending on the particular quantile being estimated. Koenker and Basset (1978) estimated the $\theta$ th regression quantile by solving:

$$
\min _{\beta \in R} \sum_{i=1}^{N} \rho_{\theta}\left(\ln W_{i}-x_{i} \beta_{\theta}\right)
$$

where $\rho_{\theta}(\varepsilon)$ is check function defined as $\rho_{\theta}(\varepsilon)=\theta_{\varepsilon}$ if $\varepsilon>0$ or $\rho_{\theta}(\varepsilon)=(\theta-1) \varepsilon$ if $\varepsilon<0$. The standard errors of the models are obtained by bootstrap methods proposed by Buchinsky (1998).

4 For instance, wage inequality might increase at the upper tail of the distribution, while this might decrease at the lower tails (Frölich \& Melly, 2010).

5 According to Mincer (1974), the wage differentials could be result from the differences in the human capital endowments. The higher human capital endowment leads to higher productivity and thus this positive impact on productivity would increase the wage of the individuals. 
The least absolute deviation (LAD) estimator of is obtained by setting $=0.5$ for the median regression and for other specific percentiles (e.g.: $\theta=0.10, \theta=0.25, \theta=0.75$ and so on). In the present paper the quantiles are $0.10 ; 0.25 ; 0.50 ; 0.75$ and 0.90 . Note that, the coefficients differ depending on the specific quantile being estimated.

\section{The Differentiated Ways of Finding Job in Turkish Labor Market}

The focus of this subsection is to reveal labor market conditions for the job search job in Turkey. By configuring some crucial graphs for the job search, it is intended to put clear evidence for the current situation. Figure 1 represents the different ways of finding the current job over the years. As seen from the figure, the employed people mostly find their current job by themselves. This way of finding a job has the highest ratio among the others throughout the years. The second highest way of finding a job is using network channels. In that sense, the results yield that the network channels are a common way of finding a job for Turkey and it never loses its weight for the represented years. It has an increasing trend during the years 2004-2016. When the two important factors for finding a job is compared, it is revealed that, while the importance of the "network" is increased, the importance of "by own" is decreased. For instance, finding a job "by own" has a $72 \%$ share in 2004 while it decreased to $60 \%$ in 2016 (Appendix Table A).

Figure: 1

The Different Ways of Finding the Job by Years

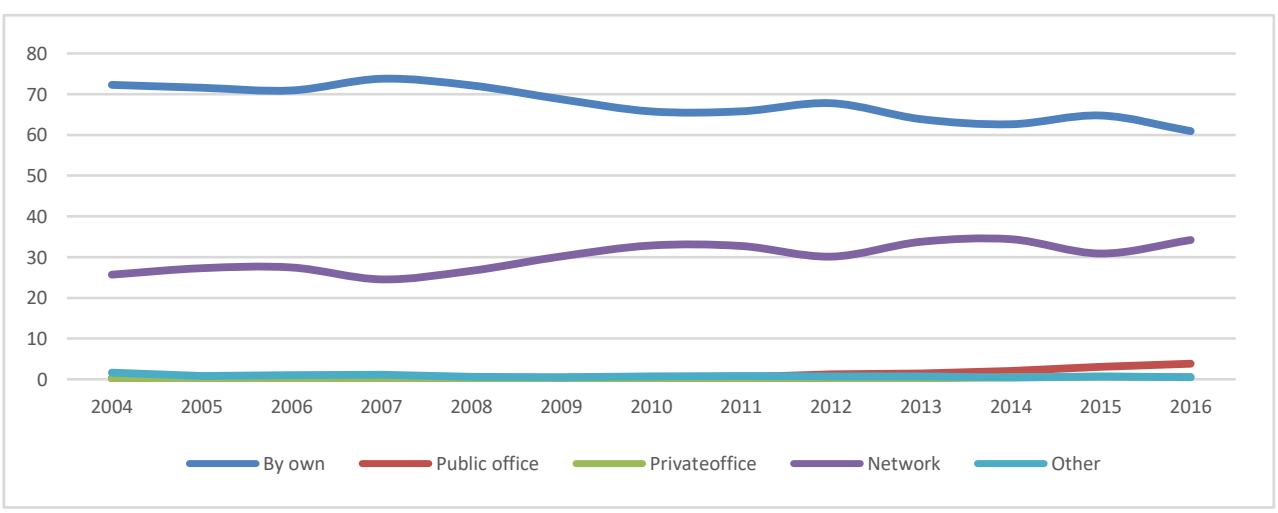

Another important issue for finding a job relies on the fact of gender differences. Therefore, Figure 2 indicates the differences between the attitudes of women and men for finding a job. According to the figure, both of them mostly prefer to find a job by themselves. The percentage of this way is around $66 \%$ for women and $68 \%$ for men. Besides, the network channels have second priority for both of them. The rate of the network is nearly the same, around $\% 30$ for both them. The striking point of the results is that there seems to exist no significant differences between women and men in terms of ways of finding the job. 


\section{Figure: 2}

\section{The Different Ways of Finding A Job}

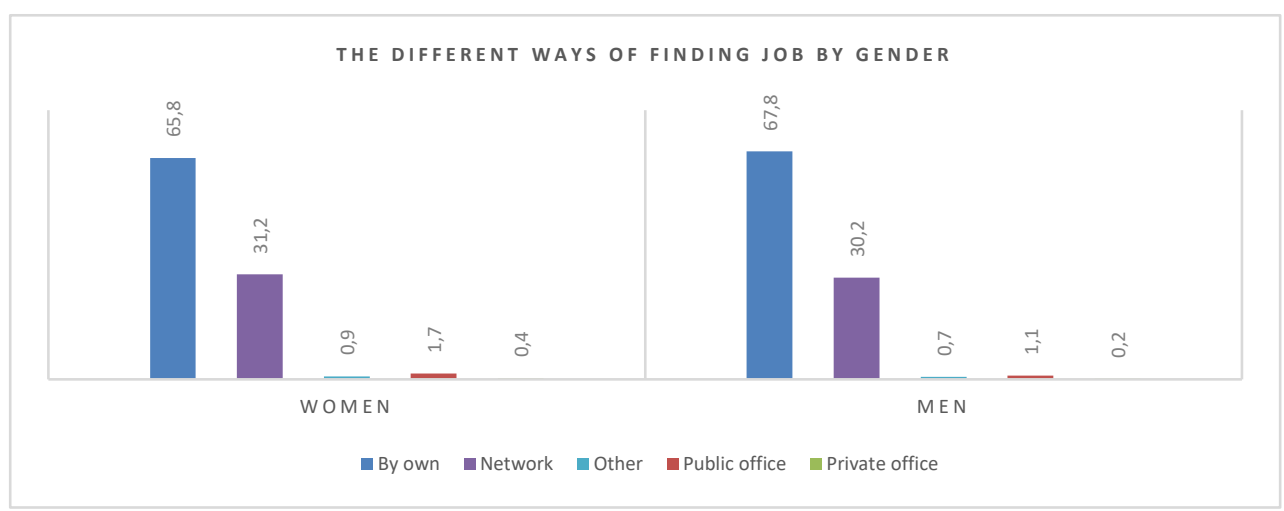

The next figure, Figure 3, shows the different ways of finding jobs for different education levels. For the higher education levels, the percentage of finding the current job by "networks" is decreased compared to the lower levels. Besides, as education level increases, the percentage of finding the current job by "private office" is also increasing. For general and vocational high school graduates, percentages of finding job are similar.

\section{Figure: 3}

\section{Different Ways of Finding the Current Job by Education}

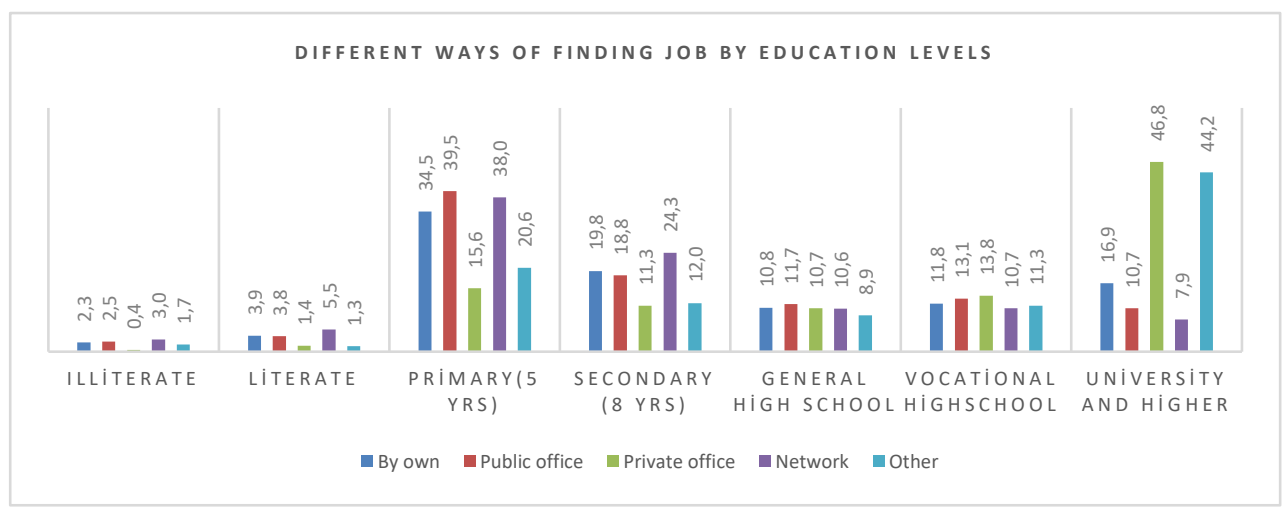

Figure 4 represents the differences between the regions (NUTS2 levels) for the looking ways of finding the current job. It is clear that, for all different regions, the percentage of finding the current job by "by own" is higher than the other options. The second higher percentage is coming from finding the current job by "networks" again for all different regions. 
Figure: 4

Different Ways of Finding the Current Job by Regions (NUTS2)

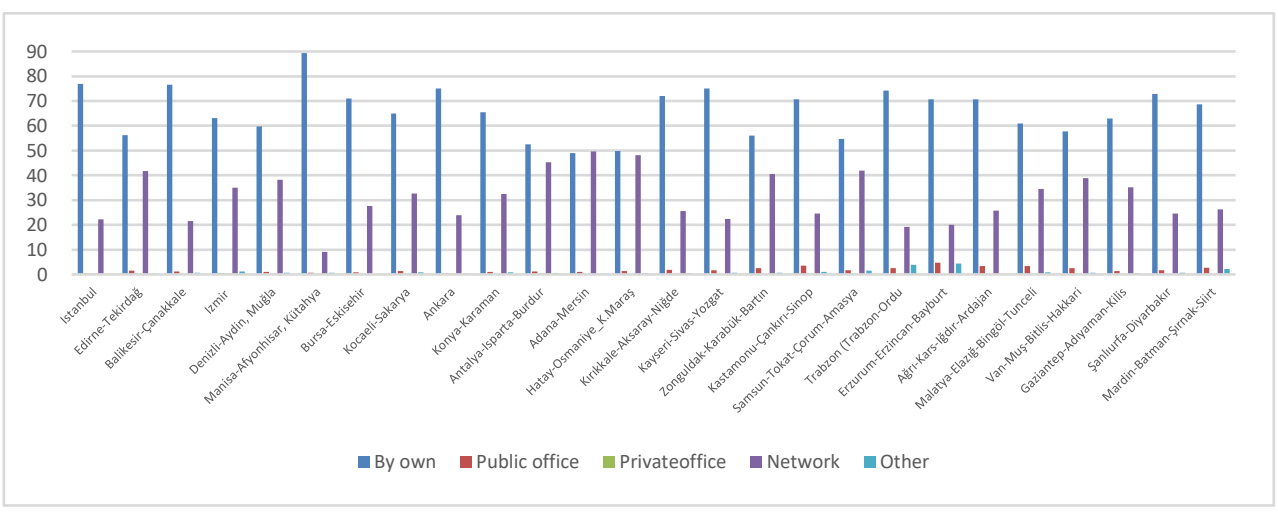

\section{Empirical Results}

The tables at which the wage quantiles regression's results are presented are given in this section. At first, the model is estimated by employing OLS technique and then for the quantile regression results are obtained for different quantiles $(0.25,0.50,0.75$, and 0.90 quantiles). Appendix-Table B.1 represents the OLS regression results where Table B.2 represents the quantile regressions. In Appendix Table B.2, the first column called "Total" includes the explanatory variables such as individual characteristics, the ways of finding a current job, years for males and females altogether. Second and third columns are females and males, respectively. The fourth column called "Total Education" shows the model where education dummies are included in the "Total" model. Fifth and sixth columns are the models for females and males where the same explanatory variables are utilized in "Total Education". The seventh column called "Total Region" represents the model where region dummies are included in "Total Education". The others are again for females and males' version of "Total Region" model ${ }^{6}$. Therefore, there are nine different model estimates. In the regressions, female, finding the current job by "own", being inactive in the previous year, illiterate and Istanbul denote the base category.

In this section, Table 2 is utilized in order to examine the results; however, for more details on quantile regression results, one can look at Appendix B. In order to reveal the changes in Table 2, the coefficients are highlighted, by doing so, a sign or significance of the coefficients change will be seen easily. Looking at the results of the regression from Table 2, it is examined that finding a job through social contacts leads to a decrease in wages. 
This result is valid not only for all different quantiles but also for all of the different models. In addition to that, there is no significant difference with respect to gender. Although previous studies found out that social network leads to an increase in the possibility of finding a job, the job found by using social contacts may not be the job that the individual is more productive. This may be because of finding a job through social contacts may lead to a mismatch between occupational choices and productive advantages of the workers. From this point of view, having a mismatch in the labor market results in a low return to the firm and thus results in a decrease in aggregate productivity.

The "Total Region" model results reveal that the impact of the way of "network" channels on wages is significant and negative for all of the different quantiles. There are changes for "private office", "public office" and "other" coefficients along with the different quantiles. Although the coefficient of "private office" was positive and significant at $25^{\text {th }}$ quantile regression, it loses its significance at higher quantiles. For the case of "public office", its effect is positive and significant at $25^{\text {th }}$ quantile. Its effect is negative at higher quantiles. The impact of "other" is positive at all the quantile regression except for the highest quantile $90^{\text {th }}$ quantiles.

Age is another controlled variable in the regression and as an individual gets older, wage increases. Examining age variable in different quantiles of the wage distribution, it is found out that the impact of it on the wages is valid for all the quantiles. A male dummy variable is also added to the regressions and it is seen that being a male leads to an increase in wages. Although the direction of the impact of being a male, the magnitude of being a male is changing for different quantiles. For example, the lowest magnitude belongs to 0.50 quantile.

For all different quantiles, education level variables have a positive effect on wage. In addition to that, as education level increases, the magnitude of the coefficient increases. For the different regions, the results yield that living in Istanbul compared to living in another region leads to decrease the wages. This is true for all different quantiles. In addition to that, as education increases, wages increase which this is valid for all different quantiles. Previous labor market situation of an individual has an impact on wages. As a previous year labor market situation, being unemployed has a positive effect on wages compared to the base category being inactive. For the case of males, being in the military, it has a positive impact as well. However, being in the school has a negative effect on wages compared to being inactive (Appendix B, Table B.2). 
Table: 2

The Results of Quantile Regression Estimation (2004-2016)

\begin{tabular}{|c|c|c|c|}
\hline & Total & Total Education & Total Region \\
\hline \multicolumn{4}{|l|}{$q 25$} \\
\hline Age & $\begin{array}{c}0.08040 * * * \\
(0.000)\end{array}$ & $\begin{array}{c}0.06678 * * * \\
(0.000)\end{array}$ & $\begin{array}{c}0.06317 * * * \\
(0.000)\end{array}$ \\
\hline Male & $\begin{array}{c}0.03794 * * * \\
(0.000)\end{array}$ & $\begin{array}{c}0.10463^{* * * *} \\
(0.000)\end{array}$ & $\begin{array}{c}0.12426^{* * * *} \\
(0.000)\end{array}$ \\
\hline Private Office & $\begin{array}{c}0.11012 * * * \\
(0.000)\end{array}$ & $\begin{array}{c}0.06996 * * * \\
(0.000)\end{array}$ & $\begin{array}{c}0.05219 * * \\
(0.000)\end{array}$ \\
\hline Public Office & $\begin{array}{c}0.02055^{*} * * \\
(0.000)\end{array}$ & $\begin{array}{c}0.05991 * * * \\
(0.000)\end{array}$ & $\begin{array}{c}0.12046^{* * * *} \\
(0.000)\end{array}$ \\
\hline Network & $\begin{array}{c}-0.07836^{* * * *} \\
(0.000)\end{array}$ & $\begin{array}{c}-0.07842^{* * * *} \\
(0.000)\end{array}$ & $\begin{array}{c}-0.04975^{* * * *} \\
(0.000)\end{array}$ \\
\hline Other & $\begin{array}{c}-0.46701 * * * \\
(0.000)\end{array}$ & $\begin{array}{c}-0.35516^{* * * *} \\
(0.000)\end{array}$ & $\begin{array}{c}-0.32150^{* * * *} \\
(0.000)\end{array}$ \\
\hline Constant & $\begin{array}{c}2.92230 * * * \\
(0.000)\end{array}$ & $\begin{array}{c}2.83452 * * * \\
(0.000)\end{array}$ & $\begin{array}{c}3.16616^{* * * *} \\
(0.000)\end{array}$ \\
\hline \multicolumn{4}{|l|}{ q50 } \\
\hline Age & $\begin{array}{c}0.05064^{* * *} \\
(0.000)\end{array}$ & $\begin{array}{c}0.04269^{* * *} \\
(0.000)\end{array}$ & $\begin{array}{c}0.04708^{* * * *} \\
(0.000)\end{array}$ \\
\hline Male & $\begin{array}{c}0.02730^{* * *} \\
(0.000)\end{array}$ & $\begin{array}{c}0.07701^{* * *} \\
(0.000)\end{array}$ & $\begin{array}{c}0.09921^{* * * *} \\
(0.000)\end{array}$ \\
\hline Private Office & $\begin{array}{c}0.10542^{* * * *} \\
(0.000)\end{array}$ & $\begin{array}{c}0.03496^{* * *} \\
(0.060)\end{array}$ & $\begin{array}{c}-0.00153 \\
(0.918)\end{array}$ \\
\hline Public Office & $\begin{array}{c}-0.04867^{* * *} \\
(0.000)\end{array}$ & $\begin{array}{c}-0.02319^{* * * *} \\
(0.000)\end{array}$ & $\begin{array}{c}0.02348^{* * * *} \\
(0.000)\end{array}$ \\
\hline Network & $\begin{array}{c}-0.05410^{* * * 8} \\
(0.000)\end{array}$ & $\begin{array}{c}-0.04727^{* * * *} \\
(0.000)\end{array}$ & $\begin{array}{c}-0.03201^{* * * *} \\
(0.000)\end{array}$ \\
\hline Other & $\begin{array}{c}-0.79792^{* * *} \\
(0.000)\end{array}$ & $\begin{array}{c}-0.58427^{* * *} \\
(0.000)\end{array}$ & $\begin{array}{c}-0.56107^{* * *} \\
(0.000)\end{array}$ \\
\hline Constant & $\begin{array}{c}3.79401^{* * * *} \\
(0.000)\end{array}$ & $\begin{array}{c}3.71376^{* * * *} \\
(0.000)\end{array}$ & $\begin{array}{c}3.79895^{* * * *} \\
(0.000)\end{array}$ \\
\hline \multicolumn{4}{|l|}{$q 75$} \\
\hline Age & $\begin{array}{c}0.05812^{* * *} \\
(0.000)\end{array}$ & $\begin{array}{c}0.03989^{* * *} \\
(0.000)\end{array}$ & $\begin{array}{c}0.04085^{* * *} \\
(0.000)\end{array}$ \\
\hline male & $\begin{array}{c}0.04325^{* * *} \\
(0.000)\end{array}$ & $\begin{array}{c}0.10624^{* * *} \\
(0.000)\end{array}$ & $\begin{array}{c}0.11853^{* * *} \\
(0.000)\end{array}$ \\
\hline Private Office & $\begin{array}{c}0.17202^{* * *} \\
(0.000)\end{array}$ & $\begin{array}{c}0.00418 \\
(0.807)\end{array}$ & $\begin{array}{l}0.00364 \\
(0.893)\end{array}$ \\
\hline Public Office & $\begin{array}{c}-0.14091^{* * * *} \\
(0.000)\end{array}$ & $\begin{array}{c}-0.08206^{* * *} \\
(0.000)\end{array}$ & $\begin{array}{c}-0.05205^{* * *} \\
(0.000)\end{array}$ \\
\hline Network & $\begin{array}{c}-0.07582^{* * *} \\
(0.000)\end{array}$ & $\begin{array}{c}-0.04231^{* * * *} \\
(0.000)\end{array}$ & $\begin{array}{c}-0.03059^{* * *} \\
(0.000)\end{array}$ \\
\hline Other & $\begin{array}{c}-0.02204 \\
(0.000)\end{array}$ & $\begin{array}{c}-0.11108^{* * *} \\
(0.000)\end{array}$ & $\begin{array}{c}-0.07765^{* *} \\
(0.000)\end{array}$ \\
\hline Constant & $\begin{array}{c}3.82183^{* * *} \\
(0.000)\end{array}$ & $\begin{array}{c}3.95441^{\text {**** }} \\
(0.000)\end{array}$ & $\begin{array}{c}4.07552^{* * * *} \\
(0.000)\end{array}$ \\
\hline \multicolumn{4}{|l|}{ q90 } \\
\hline Age & $\begin{array}{c}0.08135^{* * *} \\
(0.000)\end{array}$ & $\begin{array}{c}0.04521^{* * *} \\
(0.000)\end{array}$ & $\begin{array}{c}0.04467^{* * *} \\
(0.000)\end{array}$ \\
\hline male & $\begin{array}{c}0.03707^{* * *} \\
(0.000)\end{array}$ & $\begin{array}{c}0.16453^{* * *} \\
(0.000)\end{array}$ & $\begin{array}{c}0.16839^{* * * *} \\
(0.000)\end{array}$ \\
\hline Private Office & $\begin{array}{c}0.17979^{* * *} \\
(0.000)\end{array}$ & $\begin{array}{c}0.02082 \\
(0.511)\end{array}$ & $\begin{array}{l}0.02241 \\
(0.453)\end{array}$ \\
\hline Public Office & $\begin{array}{c}-0.29247^{* * *} \\
(0.000)\end{array}$ & $\begin{array}{c}-0.14487^{* * * *} \\
(0.000)\end{array}$ & $\begin{array}{c}-0.11635^{* * * *} \\
(0.000)\end{array}$ \\
\hline Network & $\begin{array}{c}-0.14893^{* * * *} \\
(0.000)\end{array}$ & $\begin{array}{c}-0.04847^{* * *} \\
(0.000)\end{array}$ & $\begin{array}{c}-0.03665^{* * * *} \\
(0.000)\end{array}$ \\
\hline Other & $\begin{array}{c}0.30025^{* * *} \\
(0.000)\end{array}$ & $\begin{array}{c}0.03816^{6} \\
(0.104)\end{array}$ & $\begin{array}{c}0.07979^{* * * *} \\
(0.000)\end{array}$ \\
\hline Constant & $\begin{array}{c}3.66695^{* * *} \\
(0.000)\end{array}$ & $\begin{array}{c}4.01241^{* * * *} \\
(0.000)\end{array}$ & $\begin{array}{c}4.12323^{* * *} \\
(0.000)\end{array}$ \\
\hline $\mathrm{N}$ & 145138 & 145138 & 145138 \\
\hline
\end{tabular}

Note: $p$ values are given in parenthesis. The grey color shows the insignificant variables of the model. ${ }^{*} p<0.1,{ }^{* *} p<0.05,{ }^{* * *} p<0.01$.

The obtained results of the quantile regression yield several crucial points. Firstly, the results reveal that there exist some important differences along with the conditional 
Yanık-İlhan, B. \& A.A. Bayar \& N. Korucu-Gümüşoğlu (2019), "How Do Informal Social

Networks Impact on Labor Earnings in Turkey?", Sosyoekonomi, Vol. 27(41), 183-210.

distribution of logarithmic wage distribution. At the lower tail of the wage distribution, "private office" and "public office" coefficients are positive and significant; however, these coefficients are negative for all other quantiles. Besides, the coefficients of "private office" and "public office" are insignificant for the median and the 0.75 and 0.95 quantiles. This suggests that if an individual is at the lower tail of the conditional wage distribution then the impact of finding the job by using "private office" is positive. This is valid for the impact of finding the job by using "public office", as well. However, if an individual is at the upper tail of the wage distribution then the impact of finding the job by using "private office" loses its significance. However, the wage at the top of the distribution decreased by finding the job by using "public office". For the OLS results which focused on the mean effect, the coefficients of "private office" and "public office" positive. However, the coefficient of "private office" is insignificant. For the case of "network" and "other", the effects are significant and negative.

\section{Conclusion}

As stated from the beginning of the paper, there are many ways of searching for a job. In Turkey, one of the most common ways of searching for a job is using informal social networks. From this point of view, the impact of finding the way of a job can be questioned. In this paper, the direction of the impact of informal social networks on wages is targeted. The model is quantile regression while data is 2004-2016 HLFS. First, as an important finding from this research is the fact that finding a job through social contact leads to a decrease in wages. Looking at this effect on wages whether it is changing according to the quantiles or not, the findings indicate that the result is valid for all of the quantiles. The second one is related to gender: no significant difference between males and females via the effects of social networks on wages. On the other hand, being a male leads to an increase in wages for all different quantiles as expected. Examining the regional effects on wages, living in another region other than living in İstanbul has a negative impact on wages.

Previous studies found out that social network leads to an increase in the possibility of finding a job. However, the job found by using social contacts does not show that the individual is more productive at that job because finding a job through social contacts may lead to a mismatch between the workers' occupational choices and their productive advantages. From this point of view, having a mismatch in the labor market results in a low return to the firm and thus results in a decrease in aggregate productivity.

Impact of finding a job through social networks on wages is found to be negative by Mongomery (1991), Simon and Warner (1992), Casella and Hanaki (2006), Dustman et al. (2016), Casella and Hanaki (2008), Dustmann et al. (2011), Beaman and Magruder (2012) and Brown et al. (2012). In this study, this is valid for Turkey, as well. This negative effect is probably due to the fact that referees do not pay attention to the ability of the applicants during referring them for that job. Previous studies addressed the monitoring mechanism that referees monitor the referred workers. However, as it is found out that the impact of social networks on wages is negative, it can be said that this monitoring mechanism does not work in Turkey. Therefore, it can be stated that social networks function as a 
mismatching tool between individuals' comparative advantage and their occupational choices. In other words, social networks work as a proxy for unobserved characteristics for an individual. The direction of the impact of networks on wages in Turkey looks like the one in Greece, Italy, Portugal, and the United Kingdom.

The findings in this paper can be linked with not only the supply side but also demand side of the labor market. It can be said that if an individual's reservation wage is at the bottom of the wage distribution, s/he is better off when s/he uses "private office" and "public office" during their job search via wages. For the case of the society as a whole, using "private office" and "public office" makes the society be better off, as well. This is because the job at which an individual finds by using "private office" and "public office" is the one in the occupations where the worker is more productive. For the demand side of the labor market, hiring individuals who applied for the job by using "private office" and "public office" will be more likely to be more efficient since in Turkey personal contacts probably leads to mismatch. This suggestion is probably more effective for the lower tail of the wage distribution.

\section{References}

Akerlof, G.A. \& R.E. Kranton (2000), "Economics and Identity”, Quarterly Journal of Economics, 115(3), 715-53.

Akerlof, G.A. (1980), “A Theory of Social Custom, of which Unemployment may be one Consequence”, Quarterly Journal of Economics, 94(4), 749-75.

Beaman, L.A. (2011), "Social Networks and the Dynamics of Labour Market Outcomes: Evidence from Refugees Resettled in the U.S", The Review of Economic Studies, 79(1), 128-161.

Beaman, L.A. \& J. Magruder (2012), "Who Gets the Job Referral? Evidence from a Social Networks Experiment", American Economic Review, 102(7), 3574-93.

Beggs, J.J. \& S.H. Jeanne (1997), “The Social Context of Men's and Women's Job Search Ties: Membership in Voluntary Organizations, Social Resources, and Job Search Outcomes", Sociological Perspectives, 40, 601-622.

Bentolila, S. \& C. Michelacci \& J. Suarez (2010), "Social Contacts and Occupational Choice", Economica, 77, 20-45.

Bramoullé, Y. \& G. Saint-Paul (2010), "Social networks and labor market transitions”, Labor Economics, 17, 188-195.

Brass, D.J. (1985), “Men's and Women's Networks: A Study of Interaction Patterns and Influence in an Organization", Academy of Management Journal, 28, 327-43.

Brown, M. \& E. Setren \& G. Topa (2012), "Do informal referrals lead to better matches? Evidence from a firm's employee referral system", FRB of New York Staff Report, (568).

Brown, M. \& E. Setren \& G. Topa (2016), "Do informal referrals lead to better matches? Evidence from a firm's employee referral system", Journal of Labor Economics, 34(1), 161-209.

Buchinsky, M. (1994), "Changes in the U.S. Wage Structure 1963-1987: Application of Quantile Regression”, Econometrica, 62(2), 405-458.

Buchinsky, M. (1998), "Recent Advances in Quantile Regression Models", Journal of Human Resources, 33(1), 88-126. 
Yanık-İlhan, B. \& A.A. Bayar \& N. Korucu-Gümüşoğlu (2019), "How Do Informal Social Networks Impact on Labor Earnings in Turkey?", Sosyoekonomi, Vol. 27(41), 183-210.

Campbell, K. (1988), “Gender Differences in Job-related Networks”, Work and Occupations, 15, 179-200.

Casella, A. \& N. Hanaki (2006), "Why Personal Ties cannot be Bought", The American Economic Review, 96(2), 261-264.

Casella, A. \& N. Hanaki (2008), "Information Channels in Labor Markets: On the Resilience of Referral Hiring”, Journal of Economic Behavior \& Organization, 66(3-4), 492-513.

Drentea (1998), “Consequences of Women's Formal and Informal Job Search Methods for Employment in Female-Dominated Jobs", Gender and Society, 12, 321-338.

Dustman, C. \& A. Glitz \& U. Schönberg \& H. Brücker (2016), "Referral-based Job Search Networks", Review of Economic Studies, 83, 514-546.

Dustmann, C. \& A. Glitz \& U. Schonberg (2011), "Referral-based Job Search Networks", IZA Discussion Papers, 5777, Institute for the Study of Labor (IZA).

Elliot, J.R. (1999), "Social Isolation and Labor Market Insulation: Network and Neighborhood Effects on Less-educated Urban Workers", The Sociological Quarterly, 40, 199-216.

Franzen, A. \& D. Hangartner (2006), "Social Networks and Labour Market Outcomes: The NonMonetary Benefits of Social Capital", European Sociological Review, 22(4), 353-368.

Frölich, M. \& B. Melly (2010), Estimation of quantile treatment effects with STATA, <www.alexandria.unisg.ch/EXPORT/DL/60320.pdf>, 23.07.2018.

Giulietti, C. \& M. Guzi \& Z. Zhao \& K.F. Zimmermann (2010), "Social networks and the labor market outcomes of rural to urban migrants in China”, Working Paper, IZA.

Goel, D. \& K. Lang (2009), "The Role of Social Ties in the Job Search of Recent Immigrants", Canadian Labour Market and Skills Researcher Network Working Paper, No. 5.

Hensvik, L. \& O.N. Skans (2013), "Social networks, employee selection, and labor market outcomes", Institute of Evaluation of Labor Market and Education Policy Working Paper, 2013:15.

Hölzer, H.J. (1987), "Job Search by Employed and Unemployed Youth", Industrial and Labor Relations Review, 40, 601-11.

Huffman, M.L. \& T. Lisa (2001), "Job Search Methods: Consequences for Gender-Based Earnings Inequality”, Journal of Vocational Behavior, 58, 127-141.

Ibarra, H. (1992), "Homophily and Differential Returns: Sex Differences in Network Structure and Access in an Advertising Firm", Administrative Science Quarterly, 37, 422-47.

Koenker, R. \& G. Bassett (1978), "Regression Quantiles”, Econometrica, 46(1), 33-50.

Kugler, A.D. (2003), "Employee Referrals and Efficiency Wages”, Labor Economics, 10, 531-556.

Marmaros, D. \& B. Sacerdote (2002), "Peer and Social Networks in Job Search", European Economic Review, 46, 870-79.

Mincer, J. (1974), Schooling, Experience and Earnings, Columbia University Press: New York.

Montgomery, J. (1991), "Social Networks and Labor-market Outcomes: Toward an Economic Analysis", The American Economic Review, 81, 1408-18.

Moore, G. (1990), “Structural Determinants of Men's and Women's Personal Networks", American Sociological Review, 55, 726-35.

Munshi, K. (2003), "Networks in the Modern Economy: Mexican Migrants in the U. S. Labor Market", The Quarterly Journal of Economics, 118(2), 549-599. 
Pellizzari, M. (2004), “Do Friends and Relatives Really Help in Getting a Good Job?”, CEP Discussion Paper, No 623, March.

Pistaferri, L. (1999), "Informal Networks in the Italian Labor Market", Giornale degli Economisti e Annali di Economia, 58, 355-75.

Saloner, G. (1985), “Old Boy Networks as Screening Mechanism”, Journal of Labor Economics, 3, 255-67.

Silliker, A.S. (1993), “The Role of Social Contacts in the Successful Job Search”, Journal of Employment Counseling, 30, 25-34.

Simon, C. \& J. Warner (1992), "Matchmaker, Matchmaker: The Effect of Old Boy Networks on Job Match Quality, Earnings, and Tenure", Journal of Labor Economics, 306-30.

Schmutte, I.M. (2015), "Job Referral Networks and the Determination of Earnings in Local Labor Markets", Journal of Labor Economics, 33(1), 1-32.

Straits, B.C. (1998), “Occupational Sex Segregation: The Role of Personal Ties”, Journal of Vocational Behavior, 52, 191-207.

Torres, L. \& M.L. Huffman (2002), "Social Networks and Job Search Outcomes among Male and Female Professional, Technical, and Managerial Workers", Sociological Focus, 35(1), 25-42.

\section{APPENDIX A}

Table: A.1

Ways of Finding the Current Job by Years

\begin{tabular}{|c|c|c|c|c|c|c|}
\hline & By own & Public office & Private office & Network & Other & \# of observations \\
\hline 2004 & 0.72 & 0.003 & 0.001 & 0.26 & 0.016 & 29072 \\
\hline 2005 & 0.72 & 0.002 & 0.001 & 0.27 & 0.009 & 34509 \\
\hline 2006 & 0.71 & 0.004 & 0.002 & 0.27 & 0.010 & 30505 \\
\hline 2007 & 0.74 & 0.004 & 0.001 & 0.25 & 0.011 & 31463 \\
\hline 2008 & 0.72 & 0.004 & 0.002 & 0.27 & 0.007 & 33971 \\
\hline 2009 & 0.69 & 0.004 & 0.001 & 0.30 & 0.006 & 34262 \\
\hline 2010 & 0.66 & 0.006 & 0.001 & 0.33 & 0.007 & 38559 \\
\hline 2011 & 0.66 & 0.005 & 0.002 & 0.33 & 0.008 & 42869 \\
\hline 2012 & 0.68 & 0.012 & 0.001 & 0.30 & 0.008 & 43306 \\
\hline 2013 & 0.64 & 0.015 & 0.002 & 0.34 & 0.007 & 43115 \\
\hline 2014 & 0.63 & 0.020 & 0.005 & 0.34 & 0.004 & 43953 \\
\hline 2015 & 0.65 & 0.031 & 0.006 & 0.31 & 0.007 & 44182 \\
\hline 2016 & 0.61 & 0.038 & 0.006 & 0.34 & 0.005 & 42985 \\
\hline Total & 0.67 & 0.013 & 0.003 & 0.30 & 0.008 & 492751 \\
\hline
\end{tabular}

Table: A.2

Ways of Finding the Current Job by Gender

\begin{tabular}{lcccccc}
\hline & By own & Public office & Private office & Network & Other & \# of observations \\
\hline Female & 0.66 & 0.02 & 0.004 & 0.31 & 0.01 & $\mathbf{1 3 0 7 3 8}$ \\
Male & 0.68 & 0.01 & 0.002 & 0.30 & 0.01 & $\mathbf{3 6 2 0 1 3}$ \\
Total & 0.67 & 0.01 & 0.003 & 0.30 & 0.01 & $\mathbf{4 9 2 7 5 1}$ \\
\hline
\end{tabular}

Table: A.3

Ways of Finding the Current Job by Education

\begin{tabular}{|c|c|c|c|c|c|c|}
\hline & By own & Public office & Private office & Network & Other & Total \\
\hline Illiterate & 0.02 & 0.02 & 0.004 & 0.03 & 0.02 & 0.02 \\
\hline Literate & 0.04 & 0.04 & 0.01 & 0.05 & 0.01 & 0.04 \\
\hline Primary(5 yrs) & 0.34 & 0.40 & 0.16 & 0.38 & 0.21 & 0.35 \\
\hline Secondary (8 yrs) & 0.20 & 0.19 & 0.11 & 0.24 & 0.12 & 0.21 \\
\hline General High school & 0.11 & 0.12 & 0.11 & 0.11 & 0.09 & 0.11 \\
\hline Vocational High school & 0.12 & 0.13 & 0.14 & 0.11 & 0.11 & 0.11 \\
\hline University and Higher & 0.17 & 0.11 & 0.47 & 0.08 & 0.44 & 0.14 \\
\hline \# of observations & 331415 & 6206 & 1249 & 150131 & 3750 & 492751 \\
\hline
\end{tabular}


Table: A.4

Ways of Finding the Current Job by Regions (NUTS2)

\begin{tabular}{|c|c|c|c|c|c|c|}
\hline & By own & Public office & Private office & Network & Other & \# of observations \\
\hline Istanbul (Istanbul) & 0.769 & 0.003 & 0.004 & 0.223 & 0.002 & 75978 \\
\hline Tekirdag (Tekirdağ, Edirne, Kırklareli) & 0.562 & 0.015 & 0.003 & 0.417 & 0.004 & 16697 \\
\hline Balikesir (Balıkesir, Çanakkale) & 0.766 & 0.011 & 0.001 & 0.215 & 0.007 & 14374 \\
\hline Izmir (İzmir) & 0.630 & 0.005 & 0.004 & 0.349 & 0.011 & 29387 \\
\hline Aydin (Aydın, Denizli, Muğla) & 0.597 & 0.010 & 0.004 & 0.382 & 0.007 & 19057 \\
\hline Manisa (Manisa, Afyon, Kütahya, Uşak) & 0.893 & 0.007 & 0.001 & 0.092 & 0.007 & 21665 \\
\hline Bursa (Bursa, Eskişehir, Bilecik) & 0.710 & 0.008 & 0.003 & 0.277 & 0.002 & 30904 \\
\hline Kocaeli (Kocaeli, Sakarya, Düzce, Bolu, Yalova) & 0.649 & 0.013 & 0.003 & 0.326 & 0.008 & 24552 \\
\hline Ankara (Ankara) & 0.751 & 0.004 & 0.004 & 0.238 & 0.004 & 28840 \\
\hline Konya (Konya-Karaman) & 0.655 & 0.011 & 0.001 & 0.325 & 0.008 & 25453 \\
\hline Antalya (Antalya, Isparta, Burdur) & 0.524 & 0.012 & 0.006 & 0.452 & 0.005 & 18706 \\
\hline Adana (Adana-Mersin) & 0.489 & 0.010 & 0.001 & 0.497 & 0.003 & 26146 \\
\hline Hatay (Hatay, Kahramanmaraş, Osmaniye) & 0.498 & 0.013 & 0.001 & 0.482 & 0.005 & 16148 \\
\hline Kırıkkale (Kırıkkale, Aksaray, Niğde, Nevşehir, Kırşehir) & 0.721 & 0.018 & 0.000 & 0.256 & 0.005 & 12967 \\
\hline Kayseri (Kayseri, Sivas, Yozgat) & 0.751 & 0.017 & 0.002 & 0.224 & 0.006 & 10778 \\
\hline Zonguldak (Zonguldak,Karabük, Bartın) & 0.560 & 0.025 & 0.002 & 0.406 & 0.007 & 7537 \\
\hline Kastamonu (Kastamonu, Çankırı, Sinop) & 0.707 & 0.035 & 0.001 & 0.246 & 0.010 & 8067 \\
\hline Samsun (Samsun, Tokat, Çorum, Amasya) & 0.547 & 0.017 & 0.002 & 0.419 & 0.016 & 17608 \\
\hline Trabzon (Trabzon, Ordu, Giresun, Rize, Artvin, Gümüşhane) & 0.741 & 0.026 & 0.002 & 0.192 & 0.039 & 15703 \\
\hline Erzurum (Erzurum, Erzincan, Bayburt) & 0.707 & 0.047 & 0.001 & 0.201 & 0.045 & 7731 \\
\hline Ağrı (Ağrı, Kars, Iğdır, Ardahan) & 0.706 & 0.033 & 0.000 & 0.258 & 0.002 & 8802 \\
\hline Malatya (Malatya, Elazı̆̆, Bingöl, Tunceli) & 0.610 & 0.034 & 0.001 & 0.346 & 0.009 & 8198 \\
\hline Van (Vani, Muş, Bitlis, Hakkari) & 0.577 & 0.026 & 0.001 & 0.390 & 0.006 & 10845 \\
\hline Gaziantep (Gaziantep, Adıyaman, Kilis) & 0.629 & 0.014 & 0.001 & 0.351 & 0.005 & 13915 \\
\hline Sanliurfa (Şanlıurfa, Diyarbakır) & 0.729 & 0.017 & 0.001 & 0.246 & 0.007 & 14456 \\
\hline Mardin (Mardin, Batman, Şırnak, Siirt) & 0.687 & 0.027 & 0.001 & 0.263 & 0.022 & 8237 \\
\hline Total & 0.673 & 0.013 & 0.003 & 0.305 & 0.008 & 492751 \\
\hline
\end{tabular}




\section{APPENDIX B}

Table: B.1

\section{OLS Regression Results}

\begin{tabular}{|c|c|c|c|}
\hline & Total Region & Female Region & Male Region \\
\hline Age & $\begin{array}{c}0.05672^{* * * *} \\
(65.25)\end{array}$ & $\begin{array}{c}0.03789^{* * * *} \\
(21.43)\end{array}$ & $\begin{array}{c}0.07318^{* * *} \\
(72.85)\end{array}$ \\
\hline Age2 & $\begin{array}{c}-0.00070^{* * * *} \\
(58.59)\end{array}$ & $\begin{array}{c}-0.00050^{* * * *} \\
(19.67)\end{array}$ & $\begin{array}{c}-0.00091^{* * *} \\
(66.06)\end{array}$ \\
\hline Literate & $\begin{array}{c}0.14956^{* * *} \\
(12.72)\end{array}$ & $\begin{array}{c}0.14119^{* * * *} \\
(7.12)\end{array}$ & $\begin{array}{l}0.11552^{* * * *} \\
\quad(7.7)\end{array}$ \\
\hline Primary & $\begin{array}{c}0.15963^{* * * *} \\
(15.87)\end{array}$ & $\begin{array}{c}0.13671^{\text {*** }} \\
(8.58)\end{array}$ & $\begin{array}{c}0.12793^{* * *} \\
\quad(9.55)\end{array}$ \\
\hline Secondary & $\begin{array}{c}0.16143^{* * *} \\
(15.63)\end{array}$ & $\begin{array}{c}0.15089^{* * * *} \\
(8.96)\end{array}$ & $\begin{array}{c}0.12209^{* * *} \\
(9.00)\end{array}$ \\
\hline Highschool & $\begin{array}{c}0.34739^{* * *} \\
(32.87)\end{array}$ & $\begin{array}{c}0.42875^{* * * *} \\
(25.12)\end{array}$ & $\begin{array}{l}0.25648^{* * *} \\
(18.43)\end{array}$ \\
\hline Voc-Highschool & $\begin{array}{c}0.40294^{* * * *} \\
(37.76)\end{array}$ & $\begin{array}{c}0.49313^{* * *} \\
(28.31)\end{array}$ & $\begin{array}{c}0.31285^{\text {**** }} \\
(22.38)\end{array}$ \\
\hline Uni \& Higher & $\begin{array}{c}0.74209^{* * * *} \\
(70.48)\end{array}$ & $\begin{array}{c}0.83487^{* * *} \\
(49.4)\end{array}$ & $\begin{array}{c}0.62933^{* * * *} \\
(45)\end{array}$ \\
\hline Male & $\begin{array}{c}0.14794^{* * * *} \\
(41.52)\end{array}$ & & \\
\hline Unemployed(t-1) & $\begin{array}{c}0.16936^{* * *} \\
(38.07)\end{array}$ & $\begin{array}{c}0.10399^{* * *} \\
(16.15)\end{array}$ & $\begin{array}{c}0.09068^{* * *} \\
(11.15)\end{array}$ \\
\hline Military (t-1) & $\begin{array}{l}0.25105^{* * *} \\
(37.13)\end{array}$ & $\begin{array}{c}\text { NA } \\
(.)\end{array}$ & $\begin{array}{c}0.19596^{* * * *} \\
(20.74)\end{array}$ \\
\hline In school (t-1) & $\begin{array}{c}-0.08543^{* * *} \\
(14.98)\end{array}$ & $\begin{array}{c}-0.12432^{* * *} \\
(14.35)\end{array}$ & $\begin{array}{c}-0.15137^{* * *} \\
(16.16)\end{array}$ \\
\hline Private Office & $\begin{array}{c}0.0283 \\
(1.13)\end{array}$ & $\begin{array}{c}0.05627 \\
(1.4)\end{array}$ & $\begin{array}{c}0.00493 \\
(0.15)\end{array}$ \\
\hline Public Office & $\begin{array}{c}0.06787^{* * *} \\
\quad(6.8)\end{array}$ & $\begin{array}{c}0.19061^{* * *} \\
(11.77)\end{array}$ & $\begin{array}{c}-0.01912 \\
(1.50)\end{array}$ \\
\hline Network & $\begin{array}{c}-0.06017^{* * * *} \\
(19.73)\end{array}$ & $\begin{array}{c}-0.08536^{* * *} \\
(14.68)\end{array}$ & $\begin{array}{c}-0.04241^{* * * *} \\
(12.19)\end{array}$ \\
\hline Other & $\begin{array}{c}-0.23243^{* * * *} \\
(19.36)\end{array}$ & $\begin{array}{c}-0.23372^{* * * *} \\
(11.29)\end{array}$ & $\begin{array}{c}-0.23089^{* * * *} \\
(15.88)\end{array}$ \\
\hline Year-2005 & $\begin{array}{c}0.18572^{* * * *} \\
(22.98)\end{array}$ & $\begin{array}{c}0.15523^{* * *} \\
(9.49)\end{array}$ & $\begin{array}{c}0.19956^{* * * *} \\
(22.3)\end{array}$ \\
\hline Year-2006 & $\begin{array}{c}0.41445^{* * *} \\
(51.6)\end{array}$ & $\begin{array}{c}0.40207^{* * *} \\
(25.22)\end{array}$ & $\begin{array}{c}0.41803^{* * *} \\
(46.57)\end{array}$ \\
\hline Year-2007 & $\begin{array}{c}0.64798^{* * * *} \\
(81.02)\end{array}$ & $\begin{array}{c}0.62351^{* * * *} \\
(39.57)\end{array}$ & $\begin{array}{c}0.65963^{* * *} \\
(73.49)\end{array}$ \\
\hline Year-2008 & $\begin{array}{c}0.86120^{* * * *} \\
(107.89)\end{array}$ & $\begin{array}{c}0.83989^{* * *} \\
(53.3)\end{array}$ & $\begin{array}{c}0.87376^{* * *} \\
(97.64)\end{array}$ \\
\hline Year-2009 & $\begin{array}{c}0.97215^{* * *} \\
(123.61\end{array}$ & $\begin{array}{c}0.92497^{\text {*** }} \\
(59.22)\end{array}$ & $\begin{array}{c}0.99546^{* * * *} \\
(113.27)\end{array}$ \\
\hline Year-2010 & $\begin{array}{c}1.14160^{* * *} \\
(151.62)\end{array}$ & $\begin{array}{c}1.10712^{* * *} \\
(72.95)\end{array}$ & $\begin{array}{c}1.16029^{* * * *} \\
(138.86)\end{array}$ \\
\hline Year-2011 & $\begin{array}{c}1.31905^{* * *} \\
(177.15)\end{array}$ & $\begin{array}{c}1.26856^{* * *} \\
(85.01)\end{array}$ & $\begin{array}{c}1.34670^{* * * *} \\
(162.53)\end{array}$ \\
\hline Year-2012 & $\begin{array}{c}1.51274^{* * *} \\
(201.21)\end{array}$ & $\begin{array}{c}1.49183^{* * *} \\
(100.16)\end{array}$ & $\begin{array}{c}1.53076^{* * *} \\
(181.85)\end{array}$ \\
\hline Year-2013 & $\begin{array}{c}1.67197^{* * * *} \\
(221.06\end{array}$ & $\begin{array}{c}1.62396^{* * *} \\
(110.26)\end{array}$ & $\begin{array}{c}1.70691^{* * * *} \\
(199.41)\end{array}$ \\
\hline Year-2014 & $\begin{array}{c}1.87304^{* * *} \\
(246.54\end{array}$ & $\begin{array}{c}1.81390^{* * * *} \\
(122.54)\end{array}$ & $\begin{array}{l}1.91483^{* * *} \\
(222.75)\end{array}$ \\
\hline Year-2015 & $\begin{array}{c}2.03895^{* * *} \\
(269.38)\end{array}$ & $\begin{array}{c}1.98263^{* * *} \\
(134.76)\end{array}$ & $\begin{array}{c}2.07723^{* * * *} \\
(242.1)\end{array}$ \\
\hline Year-2016 & $\begin{array}{c}2.29723^{* * * *} \\
(297.29)\end{array}$ & $\begin{array}{c}2.24521^{* * * *} \\
(150.62)\end{array}$ & $\begin{array}{c}2.32986^{* * * *} \\
(264.64)\end{array}$ \\
\hline Tekirdag & $\begin{array}{c}-0.27495^{* * * *} \\
(32.35)\end{array}$ & $\begin{array}{c}-0.26319^{* * * *} \\
(18.54)\end{array}$ & $\begin{array}{c}-0.28753^{\text {**** }} \\
(27.26)\end{array}$ \\
\hline Balikesir & $\begin{array}{c}-0.32555^{* * * *} \\
(38.66)\end{array}$ & $\begin{array}{c}-0.33867^{* * * *} \\
(22.71)\end{array}$ & $\begin{array}{c}-0.31567^{* * * *} \\
(31.57)\end{array}$ \\
\hline Izmir & $-0.21941^{* * * *}$ & $-0.22781^{* * * *}$ & $-0.21166^{* * *}$ \\
\hline Aydin & $-0.31410^{* * * *}$ & $-0.33031^{* * * *}$ & $-0.30170^{* * * *}$ \\
\hline & $(38.51)$ & (23.83) & (30.23) \\
\hline Manisa & $\begin{array}{c}-0.30986^{* * *} \\
(40.99)\end{array}$ & $\begin{array}{c}-0.29528^{* * * *} \\
(20.58)\end{array}$ & $\begin{array}{c}-0.31175^{* * * *} \\
(36.11)\end{array}$ \\
\hline
\end{tabular}


Yanık-İlhan, B. \& A.A. Bayar \& N. Korucu-Gümüşoğlu (2019), "How Do Informal Social Networks Impact on Labor Earnings in Turkey?", Sosyoekonomi, Vol. 27(41), 183-210.

\begin{tabular}{|c|c|c|c|}
\hline & Total Region & Female Region & Male Region \\
\hline Bursa & $\begin{array}{c}-0.22327^{* * * *} \\
(34.24)\end{array}$ & $\begin{array}{c}-0.26415^{* * *} \\
(23.12)\end{array}$ & $\begin{array}{c}-0.19466^{* * *} \\
(24.94)\end{array}$ \\
\hline Kocaeli & $\begin{array}{c}-0.20076^{* * *} \\
(28.94)\end{array}$ & $\begin{array}{c}-0.24825^{* * *} \\
(19.54)\end{array}$ & $\begin{array}{c}-0.17039^{* * * *} \\
(21.11)\end{array}$ \\
\hline Ankara & $-0.13925^{* * *}$ & $-0.17678^{* * *}$ & $-0.11578^{* * * *}$ \\
\hline & (21.53) & $(15.00)$ & $(15.35)$ \\
\hline Konya & $-0.37177^{* * * *}$ & $-0.46574^{* * *}$ & $-0.31922^{* * *}$ \\
\hline & (51.72) & $(34.80)$ & $(38.51)$ \\
\hline Antalya & $-0.23152^{* * * *}$ & $-0.27552^{* * *}$ & $-0.19519^{* * * *}$ \\
\hline & (27.51) & (19.38) & $(18.85)$ \\
\hline Adana & $-0.39929^{* * * *}$ & $-0.42696^{* * *}$ & $-0.38720^{* * *}$ \\
\hline & (59.24) & (33.25) & $(50.39)$ \\
\hline Hatay & $-0.38860^{* * * *}$ & $-0.46542^{* * * *}$ & $-0.35963^{* * * *}$ \\
\hline & $(46.20)$ & $(27.56)$ & $(38.38)$ \\
\hline Kirikkale & $-0.27632^{* * * *}$ & $-0.29949^{* * *}$ & $-0.26914^{* * * *}$ \\
\hline & (29.74) & (16.39) & (25.79) \\
\hline Kayseri & $-0.26080^{* * * *}$ & $-0.31534^{* * *}$ & $-0.23444^{* * * *}$ \\
\hline & (26.30) & (15.62) & $(21.36)$ \\
\hline Zonguldak & $-0.30752^{* * * *}$ & $-0.38547^{* * * *}$ & $-0.26538^{* * *}$ \\
\hline & $(26.88)$ & (18.14) & (20.10) \\
\hline Kastamonu & $-0.29512^{* * * *}$ & $-0.29240^{* * *}$ & $-0.28358^{* * *}$ \\
\hline & $(26.48)$ & $(14.31)$ & $(21.88)$ \\
\hline Samsun & $-0.33523^{* * * *}$ & $-0.41702^{* * *}$ & $-0.29408^{* * * *}$ \\
\hline & $(39.70)$ & (26.80) & (30.04) \\
\hline Trabzon & $-0.22818^{* * * *}$ & $-0.26900^{* * *}$ & $-0.21216^{* * *}$ \\
\hline & $(28.72)$ & (17.64) & $(23.51)$ \\
\hline Erzurum & $-0.18942^{* * * *}$ & $-0.25973^{* * *}$ & $-0.16513^{* * * *}$ \\
\hline & $(17.53)$ & (11.12) & $(14.11)$ \\
\hline Ăğn & $-0.16082^{* * * *}$ & $-0.20310^{* * *}$ & $-0.15468^{* * * *}$ \\
\hline & (13.79) & (7.48) & $(12.50)$ \\
\hline Malatya & $-0.26445^{* * * *}$ & $-0.27760^{* * *}$ & $-0.25880^{* * * *}$ \\
\hline & (24.98) & (12.73) & $(22.19)$ \\
\hline Van & $-0.12388^{* * * *}$ & $-0.17074^{* * *}$ & $-0.12398^{* * * *}$ \\
\hline & (13.78) & (6.26) & $(13.54)$ \\
\hline Gaziantep & $-0.30626^{* * * *}$ & $-0.38743^{* * *}$ & $-0.28365^{* * * *}$ \\
\hline & $(35.50)$ & (20.54) & (30.39) \\
\hline Sanliurfa & $-0.20304^{* * * *}$ & $-0.12668^{* * *}$ & $-0.22569^{* * * *}$ \\
\hline & (24.24) & (6.04) & $(25.69)$ \\
\hline Mardin & $-0.27350^{* * * *}$ & $-0.16193^{* * *}$ & $-0.30094^{* * * *}$ \\
\hline & $(26.59)$ & (6.52) & (27.82) \\
\hline Constant & $3.42665^{* * *}$ & $3.84441^{* * *}$ & $3.39067^{* * *}$ \\
\hline & (184.54) & (112.44) & $(147.59)$ \\
\hline Observations & 145138 & 49254 & 95884 \\
\hline
\end{tabular}

Note: $t$ statistics are in parentheses; $* p<0.1,{ }^{* *} p<0.05, * * * p<0.01$. 
Table: B.2

Quantile Regression Results

\begin{tabular}{|c|c|c|c|c|c|c|c|c|c|}
\hline & Total & Female & Male & Total Education & Female Education & Male Education & Total Region & Female Region & Male Region \\
\hline \multicolumn{10}{|l|}{$\mathbf{9 2 5}$} \\
\hline Age & $\begin{array}{c}0.08040^{* * *} \\
(61.03)\end{array}$ & $\begin{array}{c}0.08924^{* * *} \\
(22.00)\end{array}$ & $\begin{array}{c}0.08762^{* * *} \\
(66.59)\end{array}$ & $\begin{array}{c}0.06678^{* * *} \\
(66.14)\end{array}$ & $\begin{array}{c}0.05042^{* * *} \\
(20.52)\end{array}$ & $\begin{array}{c}0.07750^{* * *} \\
(73.70)\end{array}$ & $\begin{array}{c}0.06317^{* * *} \\
(56.32)\end{array}$ & $\begin{array}{c}0.04890^{* * *} \\
(17.53)\end{array}$ & $\begin{array}{c}0.07459^{* * *} \\
(56.79)\end{array}$ \\
\hline Age2 & $\begin{array}{c}-0.00109^{* * * *} \\
(-56.53)\end{array}$ & $\begin{array}{c}-0.00136^{* * *} \\
(-21.37)\end{array}$ & $\begin{array}{c}-0.00117^{* * * *} \\
(-61.42)\end{array}$ & $\begin{array}{c}-0.00085^{* * *} \\
(-53.43)\end{array}$ & $\begin{array}{c}-0.00069^{* * *} \\
(-17.35)\end{array}$ & $\begin{array}{c}-0.00099^{* * *} \\
(-65.28)\end{array}$ & $\begin{array}{c}-0.00081^{* * *} \\
(-51.61)\end{array}$ & $\begin{array}{c}-0.00067^{* * * *} \\
(-15.25)\end{array}$ & $\begin{array}{c}-0.00096^{* * *} \\
(-53.16)\end{array}$ \\
\hline Male & $\begin{array}{c}0.03794^{* * * *} \\
(9.01)\end{array}$ & & & $\begin{array}{c}0.10463^{* * * *} \\
(19.97)\end{array}$ & & & $\begin{array}{c}0.12426^{* * *} \\
(27.29)\end{array}$ & & \\
\hline Unemployed(t-1) & $\begin{array}{c}0.31811^{* * *} \\
(36.41)\end{array}$ & $\begin{array}{c}0.33177^{* * *} \\
(29.66)\end{array}$ & $\begin{array}{c}0.06222^{* * *} \\
\quad(4.07)\end{array}$ & $\begin{array}{c}0.23335^{\text {**** }} \\
(34.90)\end{array}$ & $\begin{array}{c}0.14791^{* * *} \\
(24.37)\end{array}$ & $\begin{array}{c}0.11359^{* * *} \\
(10.27)\end{array}$ & $\begin{array}{c}0.18985^{* * *} \\
(27.06)\end{array}$ & $\begin{array}{c}0.10408^{* * *} \\
(14.54)\end{array}$ & $\begin{array}{c}0.09377^{* * *} \\
(10.48)\end{array}$ \\
\hline Military (t-1) & $\begin{array}{c}0.47514^{* * *} \\
(50.17)\end{array}$ & $\begin{array}{c}0.00000 \\
(.)\end{array}$ & $\begin{array}{c}0.24685^{* * *} \\
(15.79)\end{array}$ & $\begin{array}{c}0.33787^{\text {**** }} \\
(38.60)\end{array}$ & $\begin{array}{c}0.00000 \\
(.)\end{array}$ & $\begin{array}{c}0.25226^{* * *} \\
(22.62)\end{array}$ & $\begin{array}{c}0.28210^{* * * *} \\
(32.93)\end{array}$ & $\begin{array}{c}0.00000 \\
(.)\end{array}$ & $\begin{array}{c}0.21548^{* * * *} \\
(21.50)\end{array}$ \\
\hline In school (t-1) & $\begin{array}{c}-0.11220^{* * *} \\
(-9.17)\end{array}$ & $\begin{array}{c}-0.06776^{* * *} \\
(-2.86)\end{array}$ & $\begin{array}{c}-0.36139^{* * * *} \\
(-20.11)\end{array}$ & $\begin{array}{c}-0.18360^{* * *} \\
(-16.75)\end{array}$ & $\begin{array}{c}-0.17653^{* * *} \\
(-17.34)\end{array}$ & $\begin{array}{c}-0.31995^{* * *} \\
(-20.97)\end{array}$ & $\begin{array}{c}-0.21744^{* * *} \\
(-19.97)\end{array}$ & $\begin{array}{c}-0.19728^{* * *} \\
(-21.09)\end{array}$ & $\begin{array}{c}-0.34051^{* * *} \\
(-32.75)\end{array}$ \\
\hline Private Office & $\begin{array}{c}0.11012^{* * * *} \\
(5.82)\end{array}$ & $\begin{array}{c}0.13300^{* * * *} \\
\quad(3.76)\end{array}$ & $\begin{array}{c}0.08610^{* * * *} \\
(3.09)\end{array}$ & $\begin{array}{c}0.06996^{* * * *} \\
(4.59)\end{array}$ & $\begin{array}{c}0.13757^{* * *} \\
(4.38)\end{array}$ & $\begin{array}{c}0.04012 \\
(1.50)\end{array}$ & $\begin{array}{c}0.05219^{* *} \\
(2.00)\end{array}$ & $\begin{array}{c}0.08380^{* * * *} \\
(3.55)\end{array}$ & $\begin{array}{c}0.02091 \\
(0.75)\end{array}$ \\
\hline Public Office & $\begin{array}{c}0.02055^{* * *} \\
(4.90)\end{array}$ & $\begin{array}{c}0.09501^{* * *} \\
(6.31)\end{array}$ & $\begin{array}{c}-0.00993^{* *} \\
(-2.40)\end{array}$ & $\begin{array}{c}0.05991^{* * * *} \\
(10.59)\end{array}$ & $\begin{array}{c}0.16506^{* * *} \\
(9.37)\end{array}$ & $\begin{array}{c}-0.00399 \\
(-0.67)\end{array}$ & $\begin{array}{c}0.12046^{* * *} \\
(24.44)\end{array}$ & $\begin{array}{c}0.23728^{* * *} \\
(16.72)\end{array}$ & $\begin{array}{c}0.04962^{* * *} \\
(4.47)\end{array}$ \\
\hline Network & $\begin{array}{c}-0.07836^{* * *} \\
(-15.48)\end{array}$ & $\begin{array}{c}-0.17650^{* * * *} \\
(-15.94)\end{array}$ & $\begin{array}{c}-0.04665^{* * 8} \\
(-14.46)\end{array}$ & $\begin{array}{c}-0.07842^{* * *} \\
(-18.31)\end{array}$ & $\begin{array}{c}-0.10702^{* * * *} \\
(-12.09)\end{array}$ & $\begin{array}{c}-0.05222^{* * * *} \\
(-17.54)\end{array}$ & $\begin{array}{c}-0.04975^{* * *} \\
(-11.24)\end{array}$ & $\begin{array}{c}-0.07576^{* * * *} \\
(-9.86)\end{array}$ & $\begin{array}{c}-0.03203^{* * *} \\
(-6.85)\end{array}$ \\
\hline Other & $\begin{array}{c}-0.46701^{* * * *} \\
(-38.31)\end{array}$ & $\begin{array}{c}-0.61194^{* * * *} \\
(-20.12)\end{array}$ & $\begin{array}{c}-0.40547^{* * *} \\
(-20.66)\end{array}$ & $\begin{array}{c}-0.35516^{* * *} \\
(-30.50)\end{array}$ & $\begin{array}{c}-0.33595^{* * * *} \\
(-15.94)\end{array}$ & $\begin{array}{c}-0.34983^{* * * *} \\
(-27.33)\end{array}$ & $\begin{array}{c}-0.32150^{* * * *} \\
(-33.58)\end{array}$ & $\begin{array}{c}-0.31686^{* * *} \\
(-9.47)\end{array}$ & $\begin{array}{c}-0.31320^{* * * *} \\
(-17.55)\end{array}$ \\
\hline Year-2005 & $\begin{array}{c}0.20016^{* * * *} \\
(20.47)\end{array}$ & $\begin{array}{c}0.18712^{* * * *} \\
(7.15)\end{array}$ & $\begin{array}{c}0.19942^{* * *} \\
(23.43)\end{array}$ & $\begin{array}{c}0.19165^{* * * *} \\
(16.97)\end{array}$ & $\begin{array}{c}0.16046^{* * * *} \\
(4.95)\end{array}$ & $\begin{array}{c}0.20480^{* * * *} \\
(18.71)\end{array}$ & $\begin{array}{c}0.20410^{* * * *} \\
(18.88)\end{array}$ & $\begin{array}{c}0.17843^{* * * *} \\
(8.74)\end{array}$ & $\begin{array}{c}0.21955^{* * * *} \\
(37.22)\end{array}$ \\
\hline Year-2006 & $\begin{array}{c}0.42017^{* * * *} \\
(48.88)\end{array}$ & $\begin{array}{c}0.44801^{* * *} \\
(21.89)\end{array}$ & $\begin{array}{c}0.41183^{* * *} \\
(54.07)\end{array}$ & $\begin{array}{c}0.40416^{* * * *} \\
(31.98)\end{array}$ & $\begin{array}{c}0.42856^{* * *} \\
(17.68)\end{array}$ & $\begin{array}{c}0.40033^{* * * *} \\
(37.94)\end{array}$ & $\begin{array}{c}0.42631^{* * *} \\
(40.20)\end{array}$ & $\begin{array}{c}0.43611^{* * * *} \\
(18.99)\end{array}$ & $\begin{array}{c}0.42843^{* * * *} \\
(44.54)\end{array}$ \\
\hline Year-2007 & $\begin{array}{c}0.62747^{* * * *} \\
(56.62)\end{array}$ & $\begin{array}{c}0.66346^{* * *} \\
(27.70)\end{array}$ & $\begin{array}{c}0.61865^{* * *} \\
(86.16)\end{array}$ & $\begin{array}{c}0.62746^{\text {s*** }} \\
(65.88)\end{array}$ & $\begin{array}{c}0.63646^{* * * *} \\
(26.64)\end{array}$ & $\begin{array}{c}0.61505^{* * * *} \\
(70.10)\end{array}$ & $\begin{array}{c}0.65674^{* * * *} \\
(67.57)\end{array}$ & $\begin{array}{c}0.66104^{* * * *} \\
(30.02)\end{array}$ & $\begin{array}{c}0.65563^{* * * *} \\
(82.53)\end{array}$ \\
\hline Year-2008 & $\begin{array}{c}0.84027^{* * * *} \\
(79.09)\end{array}$ & $\begin{array}{c}0.86858^{* * * *} \\
(44.93)\end{array}$ & $\begin{array}{c}0.83101^{* * *} \\
(110.36)\end{array}$ & $\begin{array}{c}0.84138^{* * * *} \\
(78.79)\end{array}$ & $\begin{array}{c}0.86522^{* * * *} \\
(39.25)\end{array}$ & $\begin{array}{c}0.83262^{* * * *} \\
(99.23)\end{array}$ & $\begin{array}{c}0.87171^{* * * *} \\
(76.38)\end{array}$ & $\begin{array}{c}0.88960^{* * * *} \\
(48.94)\end{array}$ & $\begin{array}{c}0.87004^{* * * *} \\
(87.68)\end{array}$ \\
\hline Year-2009 & $\begin{array}{c}0.97637^{* * *} \\
(92.29)\end{array}$ & $\begin{array}{c}0.94941^{* * * *} \\
(36.76)\end{array}$ & $\begin{array}{c}0.97752^{* * * *} \\
(126.43)\end{array}$ & $\begin{array}{c}0.96356^{* * *} \\
(88.35)\end{array}$ & $\begin{array}{c}0.94668^{* * * *} \\
(42.70)\end{array}$ & $\begin{array}{c}0.96921^{* * * *} \\
(71.15)\end{array}$ & $\begin{array}{c}0.98715^{* * *} \\
(104.84)\end{array}$ & $\begin{array}{l}0.98012^{* * * *} \\
(42.79)\end{array}$ & $\begin{array}{c}0.99950^{* * * *} \\
(117.95)\end{array}$ \\
\hline Year-2010 & $\begin{array}{c}1.15524^{* * *} \\
(123.89)\end{array}$ & $\begin{array}{c}1.14600^{* * * *} \\
(56.66)\end{array}$ & $\begin{array}{c}1.15538^{* * * *} \\
(145.19)\end{array}$ & $\begin{array}{c}1.13879^{* * * *} \\
(96.54)\end{array}$ & $\begin{array}{c}1.12210^{* * * *} \\
(56.69)\end{array}$ & $\begin{array}{c}1.15089^{* * * *} \\
(92.50)\end{array}$ & $\begin{array}{c}1.15703^{* * *} \\
(138.55)\end{array}$ & $\begin{array}{c}1.14147^{* * * *} \\
(48.86)\end{array}$ & $\begin{array}{c}1.17388^{* * * *} \\
(110.89)\end{array}$ \\
\hline Year-2011 & $\begin{array}{c}1.33394^{* * * *} \\
(115.62)\end{array}$ & $\begin{array}{c}1.31408^{* * * *} \\
(71.65)\end{array}$ & $\begin{array}{c}1.34152^{* * * *} \\
(208.30)\end{array}$ & $\begin{array}{c}1.31880^{* * * *} \\
(117.62)\end{array}$ & $\begin{array}{c}1.29321^{* * * *} \\
(54.04)\end{array}$ & $\begin{array}{c}1.33026^{* * * *} \\
(153.47)\end{array}$ & $\begin{array}{c}1.33847^{* * * *} \\
(137.18)\end{array}$ & $\begin{array}{c}1.31200^{* * * *} \\
(68.11)\end{array}$ & $\begin{array}{c}1.35843^{* * * *} \\
(146.47)\end{array}$ \\
\hline Year-2012 & $\begin{array}{c}1.53492^{* * * *} \\
(164.62)\end{array}$ & $\begin{array}{c}1.55383^{* * *} \\
(82.18)\end{array}$ & $\begin{array}{c}1.52720^{* * * *} \\
(197.92)\end{array}$ & $\begin{array}{c}1.51852^{* * * *} \\
(145.63)\end{array}$ & $\begin{array}{c}1.51272^{* * * *} \\
(66.54)\end{array}$ & $\begin{array}{c}1.51563^{* * *} \\
(160.57)\end{array}$ & $\begin{array}{c}1.53540^{* * * *} \\
(162.58)\end{array}$ & $\begin{array}{c}1.53312^{* * * *} \\
(66.19)\end{array}$ & $\begin{array}{c}1.54482^{* * * *} \\
(144.08)\end{array}$ \\
\hline Year-2013 & $\begin{array}{c}1.69924^{* * * *} \\
(149.44)\end{array}$ & $\begin{array}{c}1.69062^{* * * *} \\
(80.65)\end{array}$ & $\begin{array}{c}1.70458^{* * * *} \\
(192.31)\end{array}$ & $\begin{array}{c}1.67089^{* * * *} \\
(129.70)\end{array}$ & $\begin{array}{c}1.63092^{* * * *} \\
(66.74)\end{array}$ & $\begin{array}{c}1.69102^{* * * *} \\
(189.44)\end{array}$ & $\begin{array}{c}1.68420^{* * * *} \\
(186.76)\end{array}$ & $\begin{array}{c}1.65508^{* * * *} \\
(81.00)\end{array}$ & $\begin{array}{c}1.71164^{* * * *} \\
(158.29)\end{array}$ \\
\hline Year-2014 & $\begin{array}{c}1.90192^{* * *} \\
(146.33)\end{array}$ & $\begin{array}{c}1.89403^{* * *} \\
(85.20)\end{array}$ & $\begin{array}{c}1.90798^{* * *} \\
(273.20)\end{array}$ & $\begin{array}{c}1.87340^{* * * *} \\
(216.46)\end{array}$ & $\begin{array}{c}1.81747^{* * * *} \\
(98.89)\end{array}$ & $\begin{array}{c}1.89794^{* * *} \\
(197.39)\end{array}$ & $\begin{array}{c}1.89320^{* * *} \\
(177.95)\end{array}$ & $\begin{array}{c}1.83360^{* * * *} \\
(87.03)\end{array}$ & $\begin{array}{c}1.92615^{* * *} \\
(157.36)\end{array}$ \\
\hline Year-2015 & $\begin{array}{c}2.07608^{* * *} \\
(239.58)\end{array}$ & $\begin{array}{c}2.07219^{* * * *} \\
(146.22)\end{array}$ & $\begin{array}{c}2.08356^{* * *} \\
(214.82)\end{array}$ & $\begin{array}{c}2.04630^{* * * *} \\
(183.03)\end{array}$ & $\begin{array}{c}1.97262^{* * * *} \\
(89.30)\end{array}$ & $\begin{array}{c}2.07292^{* * * *} \\
(223.83)\end{array}$ & $\begin{array}{l}2.06088^{* * *} \\
(209.27)\end{array}$ & $\begin{array}{c}2.00232^{* * * *} \\
(82.29)\end{array}$ & $\begin{array}{c}2.09390^{* * * *} \\
(253.48)\end{array}$ \\
\hline Year-2016 & $\begin{array}{c}2.38136^{* * *} \\
(250.14)\end{array}$ & $\begin{array}{c}2.35166^{* * * *} \\
(150.80)\end{array}$ & $\begin{array}{c}2.38575^{* * *} \\
(362.99)\end{array}$ & $\begin{array}{c}2.32292^{* * * *} \\
(257.28)\end{array}$ & $\begin{array}{c}2.26281^{* * * *} \\
(93.66)\end{array}$ & $\begin{array}{c}2.35090^{* * * *} \\
(220.93)\end{array}$ & $\begin{array}{c}2.33301^{* * *} \\
(207.33)\end{array}$ & $\begin{array}{c}2.27732^{* * * *} \\
(114.54)\end{array}$ & $\begin{array}{c}2.36577^{* * * *} \\
(276.43)\end{array}$ \\
\hline
\end{tabular}




\begin{tabular}{|c|c|c|c|c|c|c|c|c|c|}
\hline & Total & Female & Male & Total Education & Female Education & Male Education & Total Region & Female Region & Male Region \\
\hline Literate & & & & $0.17625^{* * *}$ & $0.21687^{* * *}$ & $0.11259^{* * *}$ & $0.15009^{* * *}$ & $0.16650^{* * *}$ & $0.09985^{* * *}$ \\
\hline & & & & (7.38) & $(4.30)$ & $(5.67)$ & (11.49) & $(4.40)$ & $(4.89)$ \\
\hline Primary & & & & $0.22141^{* * * *}$ & $0.18146^{* * *}$ & $0.16889^{* * *}$ & $0.18423^{* * * *}$ & $0.18047^{* * *}$ & $0.12689^{* * * *}$ \\
\hline & & & & $(9.08)$ & $(4.52)$ & $(13.84)$ & $(13.90)$ & $(6.54)$ & $(6.20)$ \\
\hline Secondary & & & & $0.19240^{* * * *}$ & $0.15406^{* * *}$ & $0.14682^{* * *}$ & $0.15557^{* * * *}$ & $0.12170^{* * *}$ & $0.11194^{* * * *}$ \\
\hline & & & & $(8.08)$ & $(3.76)$ & (10.88) & $(11.10)$ & $(3.38)$ & $(5.35)$ \\
\hline Highschool & & & & $0.36996^{* * *}$ & $0.55025^{* * *}$ & $0.25560^{* * *}$ & $0.33155^{* * *}$ & $0.46867^{* * *}$ & $0.22466^{* * *}$ \\
\hline & & & & $(15.40)$ & (14.61) & $(20.27)$ & $(26.20)$ & (15.58) & $(9.51)$ \\
\hline Voc-Highschool & & & & $0.41163^{\xi * *}$ & $0.60175^{* * *}$ & $0.30916^{* * *}$ & $0.37525^{* * *}$ & $0.53285^{* * *}$ & $0.26750^{* * * *}$ \\
\hline & & & & $(16.44)$ & $(14.65)$ & $(22.38)$ & $(28.41)$ & $(18.00)$ & (13.11) \\
\hline Uni \& Higher & & & & $0.60628^{* * *}$ & $0.78288^{* * *}$ & $0.45507^{* * *}$ & $0.57490^{* * *}$ & $0.73876^{* * *}$ & $0.42368^{* * *}$ \\
\hline & & & & $(23.59)$ & $(19.36)$ & $(32.88)$ & $(42.67)$ & $(25.12)$ & (21.04) \\
\hline Tekirdag & & & & & & & $\begin{array}{c}-0.24021^{* * *} \\
(-2203)\end{array}$ & $\begin{array}{c}-0.25986^{* * *} \\
(-17.92)\end{array}$ & $\begin{array}{c}-0.23564^{* * *} \\
(-14.06)\end{array}$ \\
\hline Balikesir & & & & & & & $-0.32241^{* * * *}$ & $-0.38836^{* * *}$ & $-0.28067^{* * * *}$ \\
\hline & & & & & & & $(-33.27)$ & $(-32.73)$ & $(-28.47)$ \\
\hline Izmir & & & & & & & $-0.19556^{* * *}$ & $-0.23521^{* * *}$ & $-0.17449^{* * * *}$ \\
\hline Aydin & & & & & & & $\begin{array}{l}(-40.65) \\
-0.30974 * * *\end{array}$ & $\begin{array}{c}(-21.89) \\
-037590^{* * * *}\end{array}$ & $(-20.01))$ \\
\hline Ayam & & & & & & & $\begin{array}{r}-0.309 / 4 \\
(-28.79)\end{array}$ & $\begin{array}{r}-0.37590 \\
(-16.44)\end{array}$ & $\begin{array}{r}-0.25459 \\
(-25.23)\end{array}$ \\
\hline Manisa & & & & & & & $-0.28967^{* * *}$ & $-0.33320^{* * *}$ & $-0.25943^{* * *}$ \\
\hline Bursa & & & & & & & $\begin{array}{c}(-38.48) \\
-0.17846 * * *\end{array}$ & $\begin{array}{c}(-21.49) \\
-0.24743^{* * * *}\end{array}$ & $\begin{array}{c}(-37.48) \\
-0.15389^{* * * * *}\end{array}$ \\
\hline Dursa & & & & & & & $\begin{array}{r}-0.1 / 846 \\
(-26.28)\end{array}$ & $\begin{array}{c}-0.24 / 43 \\
(-17.96)\end{array}$ & $\begin{array}{r}-0.15309 \\
(-23.95)\end{array}$ \\
\hline Kocaeli & & & & & & & $-0.19161^{* * *}$ & $-0.27075^{* * *}$ & $-0.15486^{* * *}$ \\
\hline Ankara & & & & & & & $\begin{array}{c}(-26.80) \\
-0.14881^{* * * *}\end{array}$ & $\begin{array}{c}(-13.71) \\
-0.21044^{* * * *}\end{array}$ & $\begin{array}{c}(-19.32) \\
-0.12175^{* * * *}\end{array}$ \\
\hline 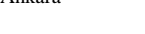 & & & & & & & $\begin{array}{r}-0.14001 \\
(-19.05)\end{array}$ & $\begin{array}{r}-0.21044 \\
(-15.74)\end{array}$ & $(-16.27)$ \\
\hline Konya & & & & & & & $-0.36827^{* * *}$ & $-0.56067^{* * *}$ & $-0.28489^{* * *}$ \\
\hline Antalya & & & & & & & $\begin{array}{c}(-37.01) \\
-0.22106^{* * * *}\end{array}$ & $\begin{array}{c}(-20.35) \\
-0.29377^{* * * *}\end{array}$ & $\begin{array}{c}(-29.05) \\
-0.17756^{* * * *}\end{array}$ \\
\hline Mindaya & & & & & & & $\begin{array}{r}-0.22100 \\
(-17.30)\end{array}$ & $\begin{array}{r}-0.295 / 1 \\
(-16.04)\end{array}$ & $\begin{array}{r}-1-14.95) \\
-(-14)\end{array}$ \\
\hline Adana & & & & & & & $-0.43910^{* * *}$ & $-0.49568^{* * *}$ & $-0.39008^{* * *}$ \\
\hline Hatay & & & & & & & $\begin{array}{c}(-54.30) \\
-0.41903^{* * *}\end{array}$ & $\begin{array}{c}(-35.28) \\
-0.55480^{* * *}\end{array}$ & $\begin{array}{c}(-35.45) \\
-0.35093^{* * *}\end{array}$ \\
\hline & & & & & & & $(-54.88)$ & $(-21.08)$ & $(-25.56)$ \\
\hline Kirikkale & & & & & & & $-0.29897^{* * * *}$ & $-0.37764^{* * *}$ & $-0.25542^{* * *}$ \\
\hline & & & & & & & $(-27.27)$ & $(-17.45)$ & $(-25.43)$ \\
\hline Kayseri & & & & & & & $-0.25653^{* * 4}$ & $-0.37994^{* * *}$ & $-0.22519^{* * *}$ \\
\hline Zonguldak & & & & & & & $\begin{array}{c}(-27.21) \\
-0.32241^{* * * *}\end{array}$ & $\begin{array}{c}(-15.01) \\
-0.43770^{* * * *}\end{array}$ & $\begin{array}{c}(-20.36) \\
-0.25854^{* * *}\end{array}$ \\
\hline & & & & & & & $(-35.06)$ & $(-15.07)$ & $(-15.44)$ \\
\hline Kastamonu & & & & & & & $-0.31813^{* * * *}$ & $-0.36903^{* * *}$ & $-0.27048^{* * * *}$ \\
\hline & & & & & & & $(-19.72)$ & $(-13.23)$ & $(-22.86)$ \\
\hline Samsun & & & & & & & $-0.38381^{* * * *}$ & $-0.48561^{* * *}$ & $-0.32585^{* * *}$ \\
\hline & & & & & & & $(-27.96)$ & $(-24.64)$ & $(-24.77)$ \\
\hline Trabzon & & & & & & & $-0.26939^{* * *}$ & $-0.32861^{* * * *}$ & $-0.23881^{* * *}$ \\
\hline Erzurum & & & & & & & $\begin{array}{c}(-41.98) \\
-0.21810^{* * * *}\end{array}$ & $\begin{array}{c}(-23.19) \\
-0.33071^{* * * *}\end{array}$ & $\begin{array}{c}(-24.34) \\
-0.18529^{* * * *}\end{array}$ \\
\hline Fats & & & & & & & $\begin{array}{r}-0.21810 \\
(-22.59)\end{array}$ & $\begin{array}{c}-0.530 / 1 \\
(-13.28)\end{array}$ & $\begin{array}{r}-0.18529 \\
(-17.29)\end{array}$ \\
\hline Ağr1 & & & & & & & $-0.26753^{* * *}$ & $-0.32924^{* * * *}$ & $-0.25262^{* * *}$ \\
\hline & & & & & & & $(-21.33)$ & $(-8.79)$ & $(-22.52)$ \\
\hline
\end{tabular}




\begin{tabular}{|c|c|c|c|c|c|c|c|c|c|}
\hline & Total & Female & Male & Total Education & Female Education & Male Education & Total Region & Female Region & Male Region \\
\hline Malatya & & & & & & & $\begin{array}{c}-0.29064^{* * *} \\
(-25.11)\end{array}$ & $\begin{array}{c}-0.35463^{* * *} \\
(-10.96)\end{array}$ & $\begin{array}{c}-0.25639^{* * *} \\
(-27.29)\end{array}$ \\
\hline Van & & & & & & & $\begin{array}{c}-0.21432^{* * * *} \\
(-21.98)\end{array}$ & $\begin{array}{c}-0.21843^{* * *} \\
(-5.80)\end{array}$ & $\begin{array}{c}-0.20486^{* * *} \\
(-19.51)\end{array}$ \\
\hline Gaziantep & & & & & & & $\begin{array}{c}-0.30584^{* * *} \\
(-33.93)\end{array}$ & $\begin{array}{c}-0.42210^{* * * *} \\
(-12.52)\end{array}$ & $\begin{array}{c}-0.28051^{* * *} \\
(-30.25)\end{array}$ \\
\hline Sanliurfa & & & & & & & $-0.26334^{* * * *}$ & $-0.23376^{* * * *}$ & $-0.25976^{* * * *}$ \\
\hline & & & & & & & $(-28.62)$ & $(-6.94)$ & $(-35.42)$ \\
\hline Mardin & & & & & & & $\begin{array}{c}-0.37187^{* * *} \\
(-23.70)\end{array}$ & $\begin{array}{c}-0.25943^{* * *} \\
(-10.01)\end{array}$ & $\begin{array}{c}-0.37562^{* * *} \\
(-27.87)\end{array}$ \\
\hline Constant & $\begin{array}{c}2.92230^{* * * *} \\
(127.42) \\
\end{array}$ & $\begin{array}{c}2.93738^{* * * *} \\
(50.38) \\
\end{array}$ & $\begin{array}{c}3.05834^{* * *} \\
(98.19) \\
\end{array}$ & $\begin{array}{c}2.83452^{* * *} \\
(93.70) \\
\end{array}$ & $\begin{array}{c}3.12575^{* * *} \\
(57.10) \\
\end{array}$ & $\begin{array}{c}2.94033^{* * *} \\
(117.36) \\
\end{array}$ & $\begin{array}{c}3.16616^{* * *} \\
(153.32) \\
\end{array}$ & $\begin{array}{c}3.47931^{* * *} \\
(62.91) \\
\end{array}$ & $\begin{array}{c}3.22543^{* * *} \\
(112.63) \\
\end{array}$ \\
\hline \multicolumn{10}{|l|}{950} \\
\hline Age & $\begin{array}{c}0.05064^{* * *} \\
(61.17)\end{array}$ & $\begin{array}{c}0.05535^{* * *} \\
(32.22)\end{array}$ & $\begin{array}{c}0.05853^{* * *} \\
(46.71)\end{array}$ & $\begin{array}{c}0.04269^{* * *} \\
(65.18)\end{array}$ & $\begin{array}{c}0.04349^{* * *} \\
(35.44)\end{array}$ & $\begin{array}{c}0.04661^{* * *} \\
(66.92)\end{array}$ & $\begin{array}{c}0.04708^{* * *} \\
(95.69)\end{array}$ & $\begin{array}{c}0.04321^{* * *} \\
(32.65)\end{array}$ & $\begin{array}{c}0.05206^{* * *} \\
(42.60)\end{array}$ \\
\hline Age2 & $\begin{array}{c}-0.00067^{* * *} \\
(-59.13)\end{array}$ & $\begin{array}{c}-0.00083^{* * *} \\
(-32.84)\end{array}$ & $\begin{array}{c}-0.00076^{* * *} \\
(-43.54)\end{array}$ & $\begin{array}{c}-0.00054^{* * *} \\
(-60.84)\end{array}$ & $\begin{array}{c}-0.00059^{* * *} \\
(-31.59)\end{array}$ & $\begin{array}{c}-0.00058^{* * *} \\
(-60.98)\end{array}$ & $\begin{array}{c}-0.00060^{* * * *} \\
(-86.99)\end{array}$ & $\begin{array}{c}-0.00059^{* * *} \\
(-27.64)\end{array}$ & $\begin{array}{c}-0.00066^{* * * *} \\
(-39.64)\end{array}$ \\
\hline Male & $\begin{array}{c}0.02730^{* * * *} \\
(10.22)\end{array}$ & & & $\begin{array}{c}0.07701^{* * *} \\
(21.50)\end{array}$ & & & $\begin{array}{c}0.09921^{* * *} \\
(33.71)\end{array}$ & & \\
\hline Unemployed(t-1) & $\begin{array}{c}0.12343^{* * * *} \\
(38.26)\end{array}$ & $\begin{array}{c}0.12326^{* * *} \\
(22.62)\end{array}$ & $\begin{array}{c}0.01766^{* * *} \\
(2.66)\end{array}$ & $\begin{array}{c}0.08772^{* * *} \\
(21.62)\end{array}$ & $\begin{array}{c}0.08454^{* * *} \\
(21.12)\end{array}$ & $\begin{array}{c}0.03983^{* * z} \\
(6.67)\end{array}$ & $\begin{array}{c}0.08180^{* * * *} \\
(27.59)\end{array}$ & $\begin{array}{c}0.05711^{* * *} \\
(11.49)\end{array}$ & $\begin{array}{c}0.03977^{* * *} \\
(6.54)\end{array}$ \\
\hline Military (t-1) & $\begin{array}{c}0.18610^{* * * *} \\
(43.89)\end{array}$ & $\begin{array}{c}0.00000 \\
(.)\end{array}$ & $\begin{array}{c}0.10249^{* * *} \\
(14.09)\end{array}$ & $\begin{array}{c}0.15510^{* * * *} \\
(31.22)\end{array}$ & $\begin{array}{c}0.00000 \\
(.)\end{array}$ & $\begin{array}{c}0.11557^{* * *} \\
(18.15)\end{array}$ & $\begin{array}{c}0.15096^{* * *} \\
(41.57)\end{array}$ & $\begin{array}{c}0.00000 \\
(.)\end{array}$ & $\begin{array}{c}0.12015^{* * *} \\
(19.25)\end{array}$ \\
\hline In school (t-1) & $\begin{array}{c}0.06637^{* * *} \\
(9.94)\end{array}$ & $\begin{array}{c}0.09417^{* * *} \\
(11.38)\end{array}$ & $\begin{array}{c}-0.06520^{* * *} \\
(-6.96)\end{array}$ & $\begin{array}{c}-0.12062^{* * *} \\
(-19.70)\end{array}$ & $\begin{array}{c}-0.07316^{* * *} \\
(-8.71)\end{array}$ & $\begin{array}{c}-0.19329^{* * *} \\
(-20.95)\end{array}$ & $\begin{array}{c}-0.10404^{* * * *} \\
(-17.82)\end{array}$ & $\begin{array}{c}-0.08696^{* * *} \\
(-11.39)\end{array}$ & $\begin{array}{c}-0.16642^{* * *} \\
(-18.40)\end{array}$ \\
\hline Private Office & $\begin{array}{c}0.10542^{* * *} \\
(5.06)\end{array}$ & $\begin{array}{c}0.08692^{* * *} \\
(3.95)\end{array}$ & $\begin{array}{c}0.10440^{* * *} \\
(3.75)\end{array}$ & $\begin{array}{c}0.03496^{* * *} \\
(3.01)\end{array}$ & $\begin{array}{c}0.06540^{* *} \\
(2.40)\end{array}$ & $\begin{array}{c}0.01519 \\
(1.20)\end{array}$ & $\begin{array}{c}-0.00153 \\
(-0.09)\end{array}$ & $\begin{array}{c}0.01324 \\
(0.32)\end{array}$ & $\begin{array}{c}-0.01997 \\
(-0.73)\end{array}$ \\
\hline Public Office & $\begin{array}{c}-0.04867^{* * *} \\
(-9.71)\end{array}$ & $\begin{array}{c}0.00758 \\
(1.45)\end{array}$ & $\begin{array}{c}-0.09225^{* * *} \\
(-19.57)\end{array}$ & $\begin{array}{c}-0.02319^{* * * *} \\
(-7.65)\end{array}$ & $\begin{array}{c}0.05036^{* * *} \\
(7.06)\end{array}$ & $\begin{array}{c}-0.06639^{* * *} \\
(-13.27)\end{array}$ & $\begin{array}{c}0.02348^{* * * *} \\
(5.33)\end{array}$ & $\begin{array}{c}0.11381^{* * *} \\
(11.59)\end{array}$ & $\begin{array}{c}-0.02685^{* * *} \\
(-3.44)\end{array}$ \\
\hline Network & $\begin{array}{c}-0.05410^{* * * *} \\
(-22.44)\end{array}$ & $\begin{array}{c}-0.08401^{* * *} \\
(-17.72)\end{array}$ & $\begin{array}{c}-0.04154^{* * *} \\
(-18.31)\end{array}$ & $\begin{array}{c}-0.04727^{* * * *} \\
(-19.22)\end{array}$ & $\begin{array}{c}-0.07522^{* * *} \\
(-14.57)\end{array}$ & $\begin{array}{c}-0.03352^{* * * *} \\
(-16.69)\end{array}$ & $\begin{array}{c}-0.03201^{* * *} \\
(-14.19)\end{array}$ & $\begin{array}{c}-0.05177^{* * * *} \\
(-8.94)\end{array}$ & $\begin{array}{c}-0.02110^{* * * *} \\
(-7.39)\end{array}$ \\
\hline Other & $\begin{array}{c}-0.79792^{* * *} \\
(-55.82)\end{array}$ & $\begin{array}{c}-0.88973^{* * *} \\
(-38.69)\end{array}$ & $\begin{array}{c}-0.70651^{* * *} \\
(-43.23)\end{array}$ & $\begin{array}{c}-0.58427^{* * *} \\
(-46.83)\end{array}$ & $\begin{array}{c}-0.62093^{* * *} \\
(-30.61)\end{array}$ & $\begin{array}{c}-0.56699^{* * *} \\
(-27.60)\end{array}$ & $\begin{array}{c}-0.56107^{* * *} \\
(-36.58)\end{array}$ & $\begin{array}{c}-0.56004^{* * *} \\
(-27.63)\end{array}$ & $\begin{array}{c}-0.53698^{* * *} \\
(-29.54)\end{array}$ \\
\hline Year-2005 & $\begin{array}{c}0.21201^{* * *} \\
(38.43)\end{array}$ & $\begin{array}{c}0.21159^{* * *} \\
(19.50)\end{array}$ & $\begin{array}{c}0.21060^{* * *} \\
(42.27)\end{array}$ & $\begin{array}{c}0.20838^{* * * *} \\
(39.27)\end{array}$ & $\begin{array}{c}0.19656^{* * *} \\
(12.74)\end{array}$ & $\begin{array}{c}0.21450^{* * * *} \\
(27.14)\end{array}$ & $\begin{array}{c}0.20892^{* * *} \\
(33.21)\end{array}$ & $\begin{array}{c}0.18601^{* * *} \\
(11.89)\end{array}$ & $\begin{array}{c}0.21365^{* * * *} \\
(52.76)\end{array}$ \\
\hline Year-2006 & $\begin{array}{c}0.41271^{* * *} \\
(89.87)\end{array}$ & $\begin{array}{c}0.41456^{* * *} \\
(34.34)\end{array}$ & $\begin{array}{c}0.41395^{* * *} \\
(68.56)\end{array}$ & $\begin{array}{c}0.41332^{* * *} \\
(63.28)\end{array}$ & $\begin{array}{c}0.40285^{* * *} \\
(25.33)\end{array}$ & $\begin{array}{c}0.40988^{* * * *} \\
(49.66)\end{array}$ & $\begin{array}{c}0.41551^{* * *} \\
(84.48)\end{array}$ & $\begin{array}{c}0.39670^{* * * *} \\
(28.98)\end{array}$ & $\begin{array}{c}0.42120^{* * * *} \\
(69.07)\end{array}$ \\
\hline Year-2007 & $\begin{array}{c}0.62406^{* * * *} \\
(82.39)\end{array}$ & $\begin{array}{c}0.61236^{* * *} \\
(41.02)\end{array}$ & $\begin{array}{c}0.62559^{* * *} \\
(97.77)\end{array}$ & $\begin{array}{c}0.62806^{* * *} \\
(122.43)\end{array}$ & $\begin{array}{c}0.61256^{* * *} \\
(49.17)\end{array}$ & $\begin{array}{c}0.62742^{* * *} \\
(79.50)\end{array}$ & $\begin{array}{c}0.63069^{* * * *} \\
(97.80)\end{array}$ & $\begin{array}{c}0.61408^{* * *} \\
(47.55)\end{array}$ & $\begin{array}{c}0.63915^{* * *} \\
(123.73)\end{array}$ \\
\hline Year-2008 & $\begin{array}{c}0.85658^{* * * *} \\
(124.43)\end{array}$ & $\begin{array}{l}0.83491^{* * *} \\
(69.44)\end{array}$ & $\begin{array}{c}0.86526^{3 * *} \\
(131.06)\end{array}$ & $\begin{array}{c}0.84803^{* * * *} \\
(146.51)\end{array}$ & $\begin{array}{c}0.82685^{* * *} \\
(68.96)\end{array}$ & $\begin{array}{c}0.85033^{* * *} \\
(131.89)\end{array}$ & $\begin{array}{c}0.85765^{* * *} \\
(136.81)\end{array}$ & $\begin{array}{c}0.83319^{* * * *} \\
(61.57)\end{array}$ & $\begin{array}{c}0.86674^{* * * *} \\
(134.77)\end{array}$ \\
\hline Year-2009 & $\begin{array}{c}0.99301^{* * *} \\
(213.47)\end{array}$ & $\begin{array}{c}0.97489^{* * *} \\
(78.36)\end{array}$ & $\begin{array}{c}0.99885^{* * *} \\
(172.51)\end{array}$ & $\begin{array}{c}0.98420^{* * *} \\
(197.17)\end{array}$ & $\begin{array}{c}0.95989^{* * *} \\
(83.55)\end{array}$ & $\begin{array}{c}0.99166^{* * *} \\
(135.19)\end{array}$ & $\begin{array}{c}0.99465^{* * *} \\
(189.28)\end{array}$ & $\begin{array}{c}0.96036^{* * *} \\
(67.81)\end{array}$ & $\begin{array}{c}1.00343^{* * * *} \\
(171.02)\end{array}$ \\
\hline Year-2010 & $\begin{array}{c}1.16221^{* * *} \\
(226.48)\end{array}$ & $\begin{array}{c}1.13822^{* * *} \\
(133.85)\end{array}$ & $\begin{array}{c}1.16696^{* * *} \\
(213.20)\end{array}$ & $\begin{array}{c}1.15139^{* * *} \\
(211.27)\end{array}$ & $\begin{array}{c}1.12232^{* * *} \\
(103.56)\end{array}$ & $\begin{array}{c}1.16259^{* * * *} \\
(146.53)\end{array}$ & $\begin{array}{c}1.15946^{* * *} \\
(265.70)\end{array}$ & $\begin{array}{c}1.12900^{* * * *} \\
(80.63)\end{array}$ & $\begin{array}{c}1.17052^{* * * *} \\
(225.16)\end{array}$ \\
\hline Year-2011 & $\begin{array}{c}1.31936^{* * *} \\
(255.93)\end{array}$ & $\begin{array}{c}1.29455^{* * *} \\
(131.01)\end{array}$ & $\begin{array}{c}1.32981^{* * *} \\
(222.74)\end{array}$ & $\begin{array}{c}1.30780^{* * * *} \\
(282.17)\end{array}$ & $\begin{array}{c}1.27169^{* * *} \\
(130.37)\end{array}$ & $\begin{array}{c}1.31733^{* * * *} \\
(179.63)\end{array}$ & $\begin{array}{c}1.32180^{* * * *} \\
(272.87)\end{array}$ & $\begin{array}{c}1.28298^{* * * *} \\
(98.89)\end{array}$ & $\begin{array}{c}1.33471^{* * * *} \\
(236.93)\end{array}$ \\
\hline Year-2012 & $\begin{array}{c}1.51348^{* * *} \\
(292.31)\end{array}$ & $\begin{array}{c}1.50155^{* * *} \\
(173.59)\end{array}$ & $\begin{array}{c}1.51656^{* * *} \\
(302.89)\end{array}$ & $\begin{array}{c}1.50353^{* * *} \\
(307.11)\end{array}$ & $\begin{array}{c}1.48964^{* * *} \\
(131.68)\end{array}$ & $\begin{array}{c}1.50521^{* * * *} \\
(201.42)\end{array}$ & $\begin{array}{c}1.51666^{* * *} \\
(366.93)\end{array}$ & $\begin{array}{c}1.49995^{* * *} \\
(106.30)\end{array}$ & $\begin{array}{c}1.52121^{* * * *} \\
(243.58)\end{array}$ \\
\hline Year-2013 & $\begin{array}{c}1.69325^{* * *} \\
(282.04)\end{array}$ & $\begin{array}{c}1.66789^{* * *} \\
(170.50)\end{array}$ & $\begin{array}{c}1.71468^{* * *} \\
(317.25)\end{array}$ & $\begin{array}{c}1.68075^{* * *} \\
(369.47)\end{array}$ & $\begin{array}{c}1.64448^{* * * *} \\
(147.01)\end{array}$ & $\begin{array}{c}1.69162^{* * *} \\
(221.17)\end{array}$ & $\begin{array}{c}1.68845^{* * *} \\
(331.48)\end{array}$ & $\begin{array}{c}1.65293^{* * * *} \\
(113.02)\end{array}$ & $\begin{array}{c}1.70472^{* * *} \\
(366.03)\end{array}$ \\
\hline Year-2014 & $\begin{array}{c}1.88518^{* * *} \\
(358.92)\end{array}$ & $\begin{array}{c}1.85826^{* * *} \\
(180.60)\end{array}$ & $\begin{array}{c}1.90677^{* * *} \\
(355.19)\end{array}$ & $\begin{array}{c}1.87550^{* * * *} \\
(464.01)\end{array}$ & $\begin{array}{c}1.82841^{* * * *} \\
(201.15)\end{array}$ & $\begin{array}{c}1.89598^{* * * *} \\
(219.99)\end{array}$ & $\begin{array}{c}1.88625^{* * *} \\
(291.54)\end{array}$ & $\begin{array}{c}1.83769^{* * * *} \\
(124.63)\end{array}$ & $\begin{array}{c}1.91359^{* * * *} \\
(254.51)\end{array}$ \\
\hline
\end{tabular}




\begin{tabular}{|c|c|c|c|c|c|c|c|c|c|}
\hline & Total & Female & Male & Total Education & Female Education & Male Education & Total Region & Female Region & Male Region \\
\hline Year-2015 & $\begin{array}{c}2.06855^{* * *} \\
(475.97)\end{array}$ & $\begin{array}{c}2.03854^{* * * *} \\
(232.24)\end{array}$ & $\begin{array}{c}2.08895^{* * *} \\
(333.04)\end{array}$ & $\begin{array}{c}2.05081^{* * *} \\
(476.40)\end{array}$ & $\begin{array}{c}2.01080^{* * * *} \\
(163.38)\end{array}$ & $\begin{array}{c}2.06520^{* * *} \\
(218.29)\end{array}$ & $\begin{array}{c}2.06126^{* * *} \\
(341.26)\end{array}$ & $\begin{array}{c}2.02640^{* * * *} \\
(151.89)\end{array}$ & $\begin{array}{c}2.08097^{* * * *} \\
(417.24)\end{array}$ \\
\hline Year-2016 & $2.38841^{* * *}$ & $2.36820^{* * * *}$ & $2.38652^{* * *}$ & $2.35275^{* * *}$ & $2.29521^{* * * *}$ & $2.36721^{* * *}$ & $2.35541^{* * * *}$ & $2.30679^{* * *}$ & $2.37609^{* * *}$ \\
\hline iterate & & & & $\begin{array}{l}(568.76) \\
011086^{* * *}\end{array}$ & $\begin{array}{l}(176.26) \\
010878^{* * *}\end{array}$ & $\begin{array}{l}(284.07) \\
00865 * * * *\end{array}$ & $(405.16)$ & $(177.74)$ & $(458.36)$ \\
\hline Literate & & & & $\begin{array}{c}0.11086^{* * *} \\
(11.75)\end{array}$ & $\begin{array}{c}0.10878^{* * *} \\
(4.85)\end{array}$ & $\begin{array}{l}0.08655^{* * a} \\
(7.55)\end{array}$ & $\begin{array}{c}0.08665^{* * *} \\
(11.46)\end{array}$ & $\begin{array}{c}0.08143^{* * *} \\
(2.62)\end{array}$ & $\begin{array}{c}0.06772^{* * *} \\
(5.07)\end{array}$ \\
\hline Primary & & & & $0.12530^{* * *}$ & $0.12707^{* * * *}$ & $0.09697^{* * *}$ & $0.10192^{* * *}$ & $0.08707^{* * * *}$ & $0.08024^{* * *}$ \\
\hline & & & & $\begin{array}{l}(12.14) \\
012538^{* * * *}\end{array}$ & $(7.87)^{* * *}$ & $\begin{array}{l}(10.88) \\
0.092)^{* * *}\end{array}$ & $(21.21)$ & (3.98) & (5.43) \\
\hline Secondary & & & & $\begin{array}{c}0.12538^{8 * 36} \\
(12.66)\end{array}$ & $\begin{array}{l}0.10812^{* * *} \\
(5.83)\end{array}$ & $\begin{array}{c}0.09928^{* * 3} \\
(10.40)\end{array}$ & $\begin{array}{l}0.10503^{* * *} \\
(22.17)\end{array}$ & $\begin{array}{c}0.08079^{* * *} \\
(3.41)\end{array}$ & $\begin{array}{c}0.08479^{\text {*at }} \\
(5.68)\end{array}$ \\
\hline Highschool & & & & $\begin{array}{c}0.22987^{* * *} \\
(21.77)\end{array}$ & $\begin{array}{c}0.27516^{* * *} \\
(17.97)\end{array}$ & $\begin{array}{c}0.17271^{* * *} \\
(18.87)\end{array}$ & $\begin{array}{c}0.21454^{* * *} \\
(39.15)\end{array}$ & $\begin{array}{c}0.25459^{* * * *} \\
(10.71)\end{array}$ & $\begin{array}{c}0.16263^{* * *} \\
(9.87)\end{array}$ \\
\hline Voc-Highschool & & & & $0.25741^{* * *}$ & $0.30349^{* * *}$ & $0.20718^{* * 8}$ & $0.24332^{* * * *}$ & $0.28552^{* * *}$ & $0.19406^{* * *}$ \\
\hline & & & & (25.14) & (18.39) & (19.49) & $(51.33)$ & (11.47) & $(12.40)$ \\
\hline Uni \& Higher & & & & $0.50086^{* * *}$ & $0.50036^{* * *}$ & $0.46440^{* * *}$ & $0.47778^{* * * *}$ & $0.49369^{* * * *}$ & $0.43353^{* * *}$ \\
\hline Tekirdag & & & & & & & $\begin{array}{l}(04.14) \\
-0.16936^{* * * *}\end{array}$ & $-0.14527^{* * *}$ & $-0.20442^{* * * *}$ \\
\hline & & & & & & & $(-21.48)$ & $(-15.77)$ & $(-19.00)$ \\
\hline Balikesir & & & & & & & $-0.24585^{* * *}$ & $-0.28602^{* * *}$ & $-0.23418^{* * * *}$ \\
\hline Izmir & & & & & & & $\begin{aligned}(-3.36))^{* * 1} & -0.15637^{* * *}\end{aligned}$ & $-0.15938^{* * * *}$ & $\begin{array}{c}(-31.56) \\
-0.16078^{* * *}\end{array}$ \\
\hline & & & & & & & $(-30.20)$ & $(-28.11)$ & $(-26.38)$ \\
\hline Aydin & & & & & & & $-0.20698^{* * *}$ & $-0.23011^{* * *}$ & $-0.20843^{* * *}$ \\
\hline Manisa & & & & & & & $\begin{array}{c}(-42.51) \\
-0.23151^{* * *}\end{array}$ & $\begin{array}{c}(-13.23) \\
-0.21727^{* * *}\end{array}$ & $\begin{array}{c}(-31.35) \\
-0.23807^{* * * *}\end{array}$ \\
\hline & & & & & & & $(-40.67)$ & $(-23.99)$ & $(-50.65)$ \\
\hline Bursa & & & & & & & $-0.14760^{* * *}$ & $-0.14844^{* * *}$ & $-0.15900^{* * *}$ \\
\hline Kocaeli & & & & & & & $\begin{array}{c}(-31.78) \\
-0.14067^{* * * *}\end{array}$ & $\begin{array}{c}(-19.42) \\
-0.16282^{* * * *}\end{array}$ & $\begin{array}{c}(-31.93) \\
-0.13630^{* * * *}\end{array}$ \\
\hline & & & & & & & $(-26.55)$ & $(-14.04)$ & $(-21.83)$ \\
\hline Ankara & & & & & & & $-0.09763^{* * *}$ & $-0.10402^{* * *}$ & $-0.09875^{* * *}$ \\
\hline Konva & & & & & & & $\begin{array}{c}(-20.82) \\
-0.23699^{* * * *}\end{array}$ & $\begin{array}{c}(-13.01) \\
-0.29853^{* * *}\end{array}$ & $\begin{array}{c}(-15.18) \\
-0.22773^{* * *}\end{array}$ \\
\hline & & & & & & & $(-43.40)$ & $(-19.88)$ & $(-40.50)$ \\
\hline Antalya & & & & & & & $-0.14333^{* * *}$ & $-0.17566^{* * *}$ & $-0.13471^{* * *}$ \\
\hline & & & & & & & $(-27.56)$ & $(-18.07)$ & $(-15.47)$ \\
\hline Adana & & & & & & & $\begin{array}{c}-0.30519^{* * *} \\
(-58.09)\end{array}$ & $\begin{array}{c}-0.35572^{* * *} \\
(-34.56)\end{array}$ & $\begin{array}{c}-0.28917^{* * *} \\
(-40.61)\end{array}$ \\
\hline Hatay & & & & & & & $-0.28431^{* * * *}$ & $-0.39840^{* * *}$ & $-0.25607^{* * *}$ \\
\hline & & & & & & & $(-48.21)$ & $(-23.20)$ & $(-27.39)$ \\
\hline Kirikkale & & & & & & & $-0.22403^{* * * *}$ & $-0.24469^{* * *}$ & $-0.22224^{* * * *}$ \\
\hline & & & & & & & $(-32.33)$ & $(-16.73)$ & $(-34.53)$ \\
\hline Kayseri & & & & & & & $-0.20395^{* * *}$ & $\begin{array}{c}-0.23664^{* * *} \\
(-14.81)\end{array}$ & $\begin{array}{c}-0.20009^{* * *} \\
(-3428)\end{array}$ \\
\hline Zonguldak & & & & & & & $\begin{aligned} & -0.24895^{* * * *}\end{aligned}$ & $-0.34879^{* * * *}$ & $-0.21745^{* * *}$ \\
\hline & & & & & & & $(-37.35)$ & $(-14.51)$ & $(-18.45)$ \\
\hline Kastamonu & & & & & & & $-0.24126^{* * *}$ & $-0.23596^{* * *}$ & $-0.24100^{* * * *}$ \\
\hline & & & & & & & $(-25.79)$ & $(-12.44)$ & $(-35.37)$ \\
\hline Samsun & & & & & & & $-0.27823^{* * *}$ & $-0.37030^{* * *}$ & $-0.25268^{* * * *}$ \\
\hline Trabzon & & & & & & & $\begin{array}{c}(-43.90) \\
-0.20627^{* * * *}\end{array}$ & $\begin{array}{c}(-18.39) \\
-0.24699^{* * * *}\end{array}$ & $\begin{array}{c}(-29.25) \\
-0.19266^{* * *}\end{array}$ \\
\hline & & & & & & & $(-34.62)$ & $(-22.01)$ & $(-19.87)$ \\
\hline
\end{tabular}




\begin{tabular}{|c|c|c|c|c|c|c|c|c|c|}
\hline & Total & Female & Male & Total Education & Female Education & Male Education & Total Region & Female Region & Male Region \\
\hline Erzurum & & & & & & & $\begin{array}{c}-0.16831^{* * * *} \\
(-18.80)\end{array}$ & $\begin{array}{c}-0.18054^{* * * *} \\
(-16.36)\end{array}$ & $\begin{array}{c}-0.17116^{* * * *} \\
(-14.05)\end{array}$ \\
\hline Ağn1 & & & & & & & $\begin{array}{c}-0.16615^{* * *} \\
(-15.26)\end{array}$ & $\begin{array}{c}-0.24020^{* * * *} \\
(-8.65)\end{array}$ & $\begin{array}{c}-0.15415^{* * *} \\
(-10.98)\end{array}$ \\
\hline Malatya & & & & & & & $-0.22930^{* * * *}$ & $-0.25752^{* * * *}$ & $-0.23009^{* * * *}$ \\
\hline Van & & & & & & & $\begin{array}{c}(-29.97) \\
-0.12152^{* * * *}\end{array}$ & $\begin{array}{c}(-9.74) \\
-0.15504^{* * *}\end{array}$ & $(-19.37)$ \\
\hline & & & & & & & $\begin{array}{r}-0.12152 \\
(-15.78)\end{array}$ & $\begin{array}{r}-0.15504 \\
(-8.63)\end{array}$ & $\begin{array}{r}-0.12594 \\
(-17.25)\end{array}$ \\
\hline Gaziantep & & & & & & & $\begin{array}{c}-0.23828^{* * * *} \\
(-47.49)\end{array}$ & $\begin{array}{c}-0.26026^{* * *} \\
(-15.33)\end{array}$ & $\begin{array}{c}-0.24248^{* * *} \\
(-27.08)\end{array}$ \\
\hline Şanliurfa & & & & & & & $\begin{array}{c}-0.20546^{* * * *} \\
(-36.96)\end{array}$ & $\begin{array}{c}-0.17157^{* * * *} \\
(-10.64)\end{array}$ & $\begin{array}{c}-0.21672^{* * *} \\
(-44.92)\end{array}$ \\
\hline Mardin & & & & & & & $\begin{array}{c}-0.26717^{* * * *} \\
(-26.63)\end{array}$ & $\begin{array}{c}-0.21792^{* * * *} \\
(-8.39)\end{array}$ & $\begin{array}{c}-0.27728^{* * *} \\
(-34.87)\end{array}$ \\
\hline Constant & $\begin{array}{c}3.79401^{* * * *} \\
(236.03) \\
\end{array}$ & $\begin{array}{c}3.82846^{* * * *} \\
(122.48) \\
\end{array}$ & $\begin{array}{c}3.76412^{* * *} \\
(174.08) \\
\end{array}$ & $\begin{array}{c}3.71376^{* * *} \\
(232.67) \\
\end{array}$ & $\begin{array}{c}3.75636 * * * \\
(149.30)\end{array}$ & $\begin{array}{c}3.78843^{* * * *} \\
(204.72) \\
\end{array}$ & $\begin{array}{c}3.79895^{* * *} \\
(384.16) \\
\end{array}$ & $\begin{array}{c}3.94948^{* * * *} \\
(134.89) \\
\end{array}$ & $\begin{array}{c}3.86487^{* * * *} \\
(159.28) \\
\end{array}$ \\
\hline \multicolumn{10}{|l|}{$\mathbf{9 7 5}$} \\
\hline Age & $\begin{array}{c}0.05812^{* * *} \\
(77.10)\end{array}$ & $\begin{array}{c}0.04684^{* * *} \\
(32.72)\end{array}$ & $\begin{array}{c}0.07151^{* * *} \\
(61.28)\end{array}$ & $\begin{array}{c}0.03989^{* * *} \\
(52.80)\end{array}$ & $\begin{array}{c}0.02495^{* * *} \\
(27.02)\end{array}$ & $\begin{array}{c}0.05191^{* * *} \\
(60.09)\end{array}$ & $\begin{array}{c}0.04085^{* * *} \\
(66.25)\end{array}$ & $\begin{array}{c}0.02851^{* * *} \\
(24.09)\end{array}$ & $\begin{array}{c}0.05180^{* * *} \\
(52.56)\end{array}$ \\
\hline Age2 & $\begin{array}{c}-0.00074^{* * *} \\
(-69.74)\end{array}$ & $\begin{array}{c}-0.00067^{* * *} \\
(-31.76)\end{array}$ & $\begin{array}{c}-0.00091^{1 * *} \\
(-52.82)\end{array}$ & $\begin{array}{c}-0.00049^{* * *} \\
(-50.06)\end{array}$ & $\begin{array}{c}-0.00033^{* * *} \\
(-24.22)\end{array}$ & $\begin{array}{c}-0.00063^{* * *} \\
(-51.26)\end{array}$ & $\begin{array}{c}-0.00050^{* * * *} \\
(-58.76)\end{array}$ & $\begin{array}{c}-0.00038^{* * *} \\
(-22.06)\end{array}$ & $\begin{array}{c}-0.00063^{* * *} \\
(-44.48)\end{array}$ \\
\hline Male & $\begin{array}{c}0.04325^{* * *} \\
(13.86)\end{array}$ & & & $\begin{array}{c}0.10624^{* * * *} \\
(27.92)\end{array}$ & & & $\begin{array}{c}0.11853^{3 * *} \\
(42.04)\end{array}$ & & \\
\hline Unemployed(t-1) & $\begin{array}{c}0.15536^{* * * *} \\
(46.03)\end{array}$ & $\begin{array}{c}0.15356^{* * *} \\
(41.44)\end{array}$ & $\begin{array}{c}0.01056 \\
(1.53)\end{array}$ & $\begin{array}{c}0.08486^{* * *} \\
(21.84)\end{array}$ & $\begin{array}{c}0.04611^{* * *} \\
(12.88)\end{array}$ & $\begin{array}{c}0.05808^{* * *} \\
(7.61)\end{array}$ & $\begin{array}{c}0.05693^{* * *} \\
(16.42)\end{array}$ & $\begin{array}{c}0.02803^{* * *} \\
(7.43)\end{array}$ & $\begin{array}{c}0.04686^{* * *} \\
(4.83)\end{array}$ \\
\hline Military $(\mathrm{t}-1)$ & $\begin{array}{c}0.23238^{* * *} \\
(35.85)\end{array}$ & $\begin{array}{c}0.00000 \\
(.)\end{array}$ & $\begin{array}{c}0.10412^{* * *} \\
(9.68)\end{array}$ & $\begin{array}{c}0.11184^{* * *} \\
(18.27)\end{array}$ & $\begin{array}{c}0.00000 \\
(.)\end{array}$ & $\begin{array}{c}0.10389^{* * *} \\
(14.19)\end{array}$ & $\begin{array}{c}0.09513^{* * *} \\
(24.11)\end{array}$ & $\begin{array}{c}0.00000 \\
(.)\end{array}$ & $\begin{array}{c}0.10037^{* * *} \\
(11.14)\end{array}$ \\
\hline In school (t-1) & $\begin{array}{c}0.18271^{* * * *} \\
(40.85)\end{array}$ & $\begin{array}{c}0.19103^{* * *} \\
(21.73)\end{array}$ & $\begin{array}{c}0.03944^{* * *} \\
(4.20)\end{array}$ & $\begin{array}{c}-0.01391^{* * *} \\
(-3.04)\end{array}$ & $\begin{array}{c}-0.04147^{* * *} \\
(-5.68)\end{array}$ & $\begin{array}{c}-0.02825^{* * *} \\
(-2.95)\end{array}$ & $\begin{array}{c}-0.03391^{* * *} \\
(-6.35)\end{array}$ & $\begin{array}{c}-0.04049^{* * *} \\
(-5.42)\end{array}$ & $\begin{array}{c}-0.03458^{* * *} \\
(-3.52)\end{array}$ \\
\hline Private Office & $\begin{array}{c}0.17202^{* * *} \\
(4.57)\end{array}$ & $\begin{array}{c}0.19807^{* * *} \\
(3.71)\end{array}$ & $\begin{array}{c}0.13900^{* * *} \\
(3.41)\end{array}$ & $\begin{array}{c}0.00418 \\
(0.23)\end{array}$ & $\begin{array}{c}0.03467 \\
(1.18)\end{array}$ & $\begin{array}{c}0.00304 \\
(0.05)\end{array}$ & $\begin{array}{c}0.00364 \\
(0.15)\end{array}$ & $\begin{array}{c}-0.00303 \\
(-0.14)\end{array}$ & $\begin{array}{c}0.00889 \\
(0.19)\end{array}$ \\
\hline Public Office & $\begin{array}{c}-0.14091^{* * *} \\
(-25.86)\end{array}$ & $\begin{array}{c}-0.07053^{* * *} \\
(-14.55)\end{array}$ & $\begin{array}{c}-0.18112^{* * *} \\
(-25.75)\end{array}$ & $\begin{array}{c}-0.08206^{* * *} \\
(-15.90)\end{array}$ & $\begin{array}{c}-0.00346 \\
(-1.44)\end{array}$ & $\begin{array}{c}-0.16401^{* * *} \\
(-19.18)\end{array}$ & $\begin{array}{c}-0.05205^{* * *} \\
(-11.82)\end{array}$ & $\begin{array}{c}0.02139^{* * * *} \\
(2.87)\end{array}$ & $\begin{array}{c}-0.12145^{* * *} \\
(-13.99)\end{array}$ \\
\hline Network & $\begin{array}{c}-0.07582^{* * *} \\
(-26.93)\end{array}$ & $\begin{array}{c}-0.09008^{* * *} \\
(-23.64)\end{array}$ & $\begin{array}{c}-0.05582^{* * *} \\
(-17.87)\end{array}$ & $\begin{array}{c}-0.04231^{* * *} \\
(-19.77)\end{array}$ & $\begin{array}{c}-0.04494^{* * *} \\
(-14.99)\end{array}$ & $\begin{array}{c}-0.03041^{* * *} \\
(-11.01)\end{array}$ & $\begin{array}{c}-0.03059^{* * *} \\
(-16.07)\end{array}$ & $\begin{array}{c}-0.04115^{* * *} \\
(-12.52)\end{array}$ & $\begin{array}{c}-0.02052^{* * *} \\
(-5.57)\end{array}$ \\
\hline Other & $\begin{array}{c}-0.02204 \\
(-0.32)\end{array}$ & $\begin{array}{c}-0.02328 \\
(-0.24)\end{array}$ & $\begin{array}{c}-0.02121 \\
(-0.32)\end{array}$ & $\begin{array}{c}-0.11108^{* * *} \\
(-3.52)\end{array}$ & $\begin{array}{c}-0.06910 \\
(-1.29)\end{array}$ & $\begin{array}{c}-0.13136^{* * *} \\
(-4.09)\end{array}$ & $\begin{array}{c}-0.07765^{* *} \\
(-2.04)\end{array}$ & $\begin{array}{c}-0.03919 \\
(-0.88)\end{array}$ & $\begin{array}{c}-0.08976^{* *} \\
(-2.10)\end{array}$ \\
\hline Year-2005 & $\begin{array}{c}0.20530^{* * * *} \\
(28.97)\end{array}$ & $\begin{array}{l}0.18500^{* * * *} \\
(12.98)\end{array}$ & $\begin{array}{c}0.20624^{* * *} \\
(28.10)\end{array}$ & $\begin{array}{c}0.20221^{* * *} \\
(23.18)\end{array}$ & $\begin{array}{c}0.17581^{* * *} \\
(18.66)\end{array}$ & $\begin{array}{c}0.20654^{* * *} \\
(25.72)\end{array}$ & $\begin{array}{c}0.19808^{* * *} \\
(27.73)\end{array}$ & $\begin{array}{c}0.18481^{* * *} \\
(20.93)\end{array}$ & $\begin{array}{c}0.20019^{* * *} \\
(28.62)\end{array}$ \\
\hline Year-2006 & $\begin{array}{c}0.41829^{* * *} \\
(62.83)\end{array}$ & $\begin{array}{c}0.39847^{* * *} \\
(20.38)\end{array}$ & $\begin{array}{c}0.43138^{* * *} \\
(63.40)\end{array}$ & $\begin{array}{c}0.40718^{* * *} \\
(57.58)\end{array}$ & $\begin{array}{c}0.37015^{* * *} \\
(36.27)\end{array}$ & $\begin{array}{c}0.43051^{* * * *} \\
(49.22)\end{array}$ & $\begin{array}{c}0.41094^{* * *} \\
(73.74)\end{array}$ & $\begin{array}{c}0.38355^{* * *} \\
(51.98)\end{array}$ & $\begin{array}{c}0.41832^{* * * *} \\
(56.97)\end{array}$ \\
\hline Year-2007 & $\begin{array}{c}0.64079^{* * *} \\
(70.70)\end{array}$ & $\begin{array}{c}0.60186^{* * *} \\
(33.70)\end{array}$ & $\begin{array}{c}0.66257^{* * *} \\
(107.38)\end{array}$ & $\begin{array}{c}0.62295^{* * *} \\
(84.95)\end{array}$ & $\begin{array}{c}0.56579^{* * *} \\
(51.89)\end{array}$ & $\begin{array}{c}0.64717^{* * * *} \\
(65.48)\end{array}$ & $\begin{array}{c}0.62694^{* * *} \\
(134.62)\end{array}$ & $\begin{array}{c}0.58981^{* * *} \\
(58.09)\end{array}$ & $\begin{array}{c}0.64704^{* * * *} \\
(92.17)\end{array}$ \\
\hline Year-2008 & $\begin{array}{c}0.87404^{* * *} \\
(115.35)\end{array}$ & $\begin{array}{c}0.84491^{* * *} \\
(73.91)\end{array}$ & $\begin{array}{c}0.88429^{* * *} \\
(81.60)\end{array}$ & $\begin{array}{c}0.85452^{* * *} \\
(130.68)\end{array}$ & $\begin{array}{c}0.80740^{* * * *} \\
(85.56)\end{array}$ & $\begin{array}{c}0.87684^{* * * *} \\
(87.23)\end{array}$ & $\begin{array}{c}0.85286^{* * *} \\
(161.86)\end{array}$ & $\begin{array}{c}0.82065^{* * *} \\
(104.62)\end{array}$ & $\begin{array}{c}0.87361^{* * * *} \\
(97.38)\end{array}$ \\
\hline Year-2009 & $\begin{array}{c}0.98954^{* * *} \\
(132.98)\end{array}$ & $\begin{array}{c}0.96649^{* * *} \\
(62.73)\end{array}$ & $\begin{array}{c}1.00308^{* * *} \\
(143.81)\end{array}$ & $\begin{array}{c}0.97407^{* * *} \\
(160.41)\end{array}$ & $\begin{array}{c}0.93437^{* * *} \\
(102.95)\end{array}$ & $\begin{array}{c}0.99911^{* * * *} \\
(97.32)\end{array}$ & $\begin{array}{c}0.98450^{* * * *} \\
(230.04)\end{array}$ & $\begin{array}{c}0.95820^{* * * *} \\
(102.60)\end{array}$ & $\begin{array}{c}1.00303^{* * * *} \\
(140.82)\end{array}$ \\
\hline Year-2010 & $\begin{array}{c}1.14625^{* * *} \\
(141.00)\end{array}$ & $\begin{array}{c}1.12070^{* * *} \\
(108.27)\end{array}$ & $\begin{array}{c}1.16136^{* * *} \\
(150.71)\end{array}$ & $\begin{array}{c}1.14636^{* * *} \\
(192.92)\end{array}$ & $\begin{array}{c}1.10808^{* * *} \\
(131.89)\end{array}$ & $\begin{array}{c}1.16552^{* * * *} \\
(110.51)\end{array}$ & $\begin{array}{c}1.15594^{* * *} \\
(236.03)\end{array}$ & $\begin{array}{c}1.12489^{* * * *} \\
(125.98)\end{array}$ & $\begin{array}{c}1.16997^{* * * *} \\
(135.82)\end{array}$ \\
\hline Year-2011 & $\begin{array}{c}1.30754^{* * * *} \\
(232.02)\end{array}$ & $\begin{array}{c}1.26287^{* * *} \\
(97.78)\end{array}$ & $\begin{array}{c}1.33257^{* * *} \\
(228.94)\end{array}$ & $\begin{array}{c}1.29458^{* * * *} \\
(172.76)\end{array}$ & $\begin{array}{c}1.24149^{* * * *} \\
(123.16)\end{array}$ & $\begin{array}{c}1.32753^{* * *} \\
(171.73)\end{array}$ & $\begin{array}{c}1.30973^{* * *} \\
(280.37)\end{array}$ & $\begin{array}{c}1.26617^{* * *} \\
(132.04)\end{array}$ & $\begin{array}{c}1.33541^{* * *} \\
(177.70)\end{array}$ \\
\hline Year-2012 & $\begin{array}{c}1.49598^{* * * *} \\
(249.44)\end{array}$ & $\begin{array}{c}1.45894^{* * *} \\
(128.51)\end{array}$ & $\begin{array}{c}1.51418^{* * *} \\
(196.97)\end{array}$ & $\begin{array}{c}1.47888^{* * *} \\
(237.11)\end{array}$ & $\begin{array}{c}1.44572^{* * * *} \\
(209.14)\end{array}$ & $\begin{array}{c}1.50450^{* * * *} \\
(209.26)\end{array}$ & $\begin{array}{c}1.49742^{* * *} \\
(417.85)\end{array}$ & $\begin{array}{c}1.47370^{* * * *} \\
(186.16)\end{array}$ & $\begin{array}{c}1.51722^{* * *} \\
(238.64)\end{array}$ \\
\hline
\end{tabular}




\begin{tabular}{|c|c|c|c|c|c|c|c|c|c|}
\hline & Total & Female & Male & Total Education & Female Education & Male Education & Total Region & Female Region & Male Region \\
\hline Year-2013 & $\begin{array}{l}1.67200^{* * *} \\
(231.37)\end{array}$ & $\begin{array}{c}1.62596^{* * *} \\
(142.88)\end{array}$ & $\begin{array}{c}1.70191^{* * *} \\
(206.41)\end{array}$ & $\begin{array}{l}1.65380^{* * *} \\
(287.73)\end{array}$ & $\begin{array}{l}1.61499^{* * * *} \\
(213.28)\end{array}$ & $\begin{array}{l}1.69089^{* * *} \\
(215.41)\end{array}$ & $\begin{array}{l}1.67278^{* * *} \\
(296.42)\end{array}$ & $\begin{array}{l}1.64007^{* * * *} \\
(210.34)\end{array}$ & $\begin{array}{c}1.70390^{* * * *} \\
(273.03)\end{array}$ \\
\hline Year-2014 & $\begin{array}{c}1.87111^{* * *} \\
(252.73)\end{array}$ & $\begin{array}{c}1.80744^{* * * *} \\
(146.23)\end{array}$ & $\begin{array}{c}1.91880^{* * * *} \\
(190.66)\end{array}$ & $\begin{array}{c}1.85440^{* * *} \\
(348.35)\end{array}$ & $\begin{array}{c}1.79270^{* * *} \\
(244.39)\end{array}$ & $\begin{array}{c}1.90415^{* * *} \\
(171.89)\end{array}$ & $\begin{array}{c}1.87116^{* * *} \\
(328.92)\end{array}$ & $\begin{array}{l}1.82526^{* * *} \\
(252.39)\end{array}$ & $\begin{array}{c}1.91246^{* * *} \\
(215.68)\end{array}$ \\
\hline Year-2015 & $\begin{array}{c}2.05412^{* * * *} \\
(358.11)\end{array}$ & $\begin{array}{l}1.99898^{* * *} \\
(161.17)\end{array}$ & $\begin{array}{c}2.09115^{* * *} \\
(289.78)\end{array}$ & $\begin{array}{c}2.03208^{* * * *} \\
(317.22)\end{array}$ & $\begin{array}{l}1.97616^{* * *} \\
(233.65)\end{array}$ & $\begin{array}{l}2.08222^{* * *} \\
(217.21)\end{array}$ & $\begin{array}{c}2.04683^{* * * *} \\
(358.57)\end{array}$ & $\begin{array}{l}2.00834^{* * *} \\
(293.12)\end{array}$ & $\begin{array}{l}2.07891^{* * * *} \\
(253.33)\end{array}$ \\
\hline Year-2016 & $\begin{array}{c}2.34149^{* * * *} \\
(337.69)\end{array}$ & $\begin{array}{l}2.30441^{* * * *} \\
(218.98)\end{array}$ & $\begin{array}{c}2.36106^{* * *} \\
(414.89)\end{array}$ & $\begin{array}{c}2.31617^{* * * *} \\
(396.41)\end{array}$ & $\begin{array}{c}2.30871^{* * * *} \\
(374.61)\end{array}$ & $\begin{array}{c}2.33720^{* * * *} \\
(203.86)\end{array}$ & $\begin{array}{c}2.33191^{* * * *} \\
(450.21)\end{array}$ & $\begin{array}{c}2.32300^{* * * *} \\
(254.20)\end{array}$ & $\begin{array}{c}2.34574^{* * *} \\
(306.75)\end{array}$ \\
\hline Literate & & & & $\begin{array}{c}0.10006^{* * * *} \\
(14.79)\end{array}$ & $\begin{array}{c}0.06428^{* * *} \\
(4.16)\end{array}$ & $\begin{array}{c}0.12836^{* * *} \\
(6.63)\end{array}$ & $\begin{array}{c}0.08015^{* * * *} \\
(9.55)\end{array}$ & $\begin{array}{l}0.06144^{* * *} \\
(5.59)\end{array}$ & $\begin{array}{l}0.08915^{* * *} \\
(9.27)\end{array}$ \\
\hline Primary & & & & $\begin{array}{c}0.08435^{* * * *} \\
(10.64)\end{array}$ & $\begin{array}{c}0.04832^{* * *} \\
(4.64)\end{array}$ & $\begin{array}{c}0.11424^{* * * *} \\
(8.05)\end{array}$ & $\begin{array}{c}0.08174^{* * *} \\
(12.06)\end{array}$ & $\begin{array}{l}0.05637^{* * *} \\
(7.57)\end{array}$ & $\begin{array}{c}0.09186^{* * *} \\
(8.58)\end{array}$ \\
\hline Secondary & & & & $\begin{array}{c}0.09980^{* * * *} \\
(12.14)\end{array}$ & $\begin{array}{c}0.07446^{* * *} \\
(6.61)\end{array}$ & $\begin{array}{l}0.12455^{* * *} \\
(7.87)\end{array}$ & $\begin{array}{c}0.09539^{* * *} \\
(14.65)\end{array}$ & $\begin{array}{l}0.07485^{* * *} \\
(9.41)\end{array}$ & $\begin{array}{c}0.10121^{* * *} \\
(8.57)\end{array}$ \\
\hline Highschool & & & & $\begin{array}{l}0.19892^{* * * *} \\
(25.40)\end{array}$ & $\begin{array}{c}0.18252^{* * *} \\
(18.61)\end{array}$ & $\begin{array}{l}0.19646^{* * *} \\
(12.04)\end{array}$ & $\begin{array}{l}0.19293^{* * * *} \\
(25.50)\end{array}$ & $\begin{array}{l}0.19008^{* * *} \\
(21.77)\end{array}$ & $\begin{array}{c}0.17150^{* * *} \\
(13.05)\end{array}$ \\
\hline Voc-Highschool & & & & $\begin{array}{l}0.22580^{* * * *} \\
(24.74)\end{array}$ & $\begin{array}{c}0.21036^{* * * *} \\
(20.12)\end{array}$ & $\begin{array}{c}0.22099^{* * * *} \\
(13.91)\end{array}$ & $\begin{array}{c}0.22455^{* * *} \\
(32.97)\end{array}$ & $\begin{array}{l}0.22197^{* * * *} \\
(22.22)\end{array}$ & $\begin{array}{l}0.20606^{* * * *} \\
(16.07)\end{array}$ \\
\hline Uni \& Higher & & & & $\begin{array}{c}0.69302^{* * *} \\
(67.33)\end{array}$ & $\begin{array}{c}0.67862^{* * * *} \\
(55.92)\end{array}$ & $\begin{array}{c}0.69276^{* * *} \\
(45.64)\end{array}$ & $\begin{array}{l}0.67248^{* * *} \\
(66.24)\end{array}$ & $\begin{array}{c}0.66125^{* * *} \\
(66.84)\end{array}$ & $\begin{array}{c}0.66192^{* * *} \\
(58.89)\end{array}$ \\
\hline Tekirdag & & & & & & & $\begin{array}{c}-0.16010^{* * *} \\
(-21.23)\end{array}$ & $\begin{array}{c}-0.12655^{* * *} \\
(-15.48)\end{array}$ & $\begin{array}{c}-0.17064^{* * *} \\
(-15.38)\end{array}$ \\
\hline Balikesir & & & & & & & $\begin{array}{c}-0.21948^{* * *} \\
(-37.56)\end{array}$ & $\begin{array}{c}-0.19596^{* * *} \\
(-17.48)\end{array}$ & $\begin{array}{c}-0.22148^{* * *} \\
(-27.02)\end{array}$ \\
\hline Izmir & & & & & & & $\begin{array}{c}-0.15559^{* * *} \\
(-29.92)\end{array}$ & $\begin{array}{c}-0.13555^{* * *} \\
(-18.56)\end{array}$ & $\begin{array}{c}-0.15505^{* * *} \\
(-23.39)\end{array}$ \\
\hline Aydin & & & & & & & $\begin{array}{c}-0.18236^{* * *} \\
(-43.45)\end{array}$ & $\begin{array}{c}-0.15678^{* * *} \\
(-17.29)\end{array}$ & $\begin{array}{c}-0.18589^{* * *} \\
(-23.05)\end{array}$ \\
\hline Manisa & & & & & & & $\begin{array}{c}-0.22573^{* * *} \\
(-30.13)\end{array}$ & $\begin{array}{c}-0.16396^{* * *} \\
(-18.31)\end{array}$ & $\begin{array}{c}-0.25327^{* * *} \\
(-47.00)\end{array}$ \\
\hline Bursa & & & & & & & $\begin{array}{c}-0.16082^{* * *} \\
(-33.93)\end{array}$ & $\begin{array}{c}-0.13483^{* * *} \\
(-22.73)\end{array}$ & $\begin{array}{c}-0.16688^{* * * *} \\
(-29.27)\end{array}$ \\
\hline Kocaeli & & & & & & & $-0.12415^{* * * *}$ & $\begin{array}{c}-0.13387^{* * *} \\
(-15.40)\end{array}$ & $-0.10988^{* * * *}$ \\
\hline Ankara & & & & & & & $-0.07037^{* * *}$ & $-0.06317^{* * * *}$ & $-0.06901^{* * *}$ \\
\hline Konya & & & & & & & $\begin{array}{c}(-13.26) \\
-0.20217^{* * *}\end{array}$ & $\begin{array}{c}(-6 . / 0) \\
-0.17341^{* * *}\end{array}$ & $\begin{array}{l}(-8.55) \\
-0.21664^{* * *}\end{array}$ \\
\hline Antalya & & & & & & & $\begin{array}{c}(-34.20) \\
-0.11904^{* * *}\end{array}$ & $\begin{array}{c}(-25.18) \\
-0.12379^{* * * *}\end{array}$ & $\begin{array}{c}(-34.08) \\
-0.10392^{* * *}\end{array}$ \\
\hline Adana & & & & & & & $\begin{array}{c}(-21.37) \\
-0.27092^{* * *}\end{array}$ & $\begin{array}{l}(-14.22) \\
-0.26339^{* * *}\end{array}$ & $\begin{array}{c}(-10.75) \\
-0.27525^{* * *}\end{array}$ \\
\hline & & & & & & & $(-47.10)$ & $(-25.57)$ & $(-36.33)$ \\
\hline Hatay & & & & & & & $\begin{array}{l}-0.24339^{* * * *} \\
(-4212)\end{array}$ & $\begin{array}{c}-0.28470^{* * * *} \\
(-15.68)\end{array}$ & $\begin{array}{l}-0.22957^{* * * *} \\
(-2889)\end{array}$ \\
\hline Kirikkale & & & & & & & $-0.19215^{* * *}$ & $-0.16454^{* * * *}$ & $-0.20655^{* * *}$ \\
\hline Kayseri & & & & & & & $\begin{array}{c}(-25.52) \\
-0.19178^{* * * *}\end{array}$ & $\begin{array}{c}(-18.38) \\
-0.17498^{* * * *}\end{array}$ & $\begin{array}{c}(-24.16) \\
-0.18139^{* * *}\end{array}$ \\
\hline & & & & & & & $(-33.48)$ & $(-18.80)$ & $(-15.93)$ \\
\hline Zonguldak & & & & & & & $-0.22792^{* * * *}$ & $-0.23938^{* * * *}$ & $-0.20600^{* * * *}$ \\
\hline Kastamonu & & & & & & & $\begin{array}{c}(-24.86) \\
-0.21200^{* * * *}\end{array}$ & $\begin{array}{c}(-16.11) \\
-0.16276^{* * * *}\end{array}$ & $\begin{array}{c}(-16.37) \\
-0.23014^{* * *}\end{array}$ \\
\hline & & & & & & & $(-22.51)$ & $(-16.89)$ & $(-28.75)$ \\
\hline
\end{tabular}




\begin{tabular}{|c|c|c|c|c|c|c|c|c|c|}
\hline & Total & Female & Male & Total Education & Female Education & Male Education & Total Region & Female Region & Male Region \\
\hline Samsun & & & & & & & $\begin{array}{c}-0.21061^{* * *} \\
(-28.31)\end{array}$ & $\begin{array}{c}-0.22997^{* * *} \\
(-18.92)\end{array}$ & $\begin{array}{c}-0.19091^{* * *} \\
(-21.79)\end{array}$ \\
\hline Trabzon & & & & & & & $-0.15810^{* * * *}$ & $-0.17661^{* * * *}$ & $-0.13038^{* * *}$ \\
\hline Erzurum & & & & & & & $\begin{array}{c}(-27.90) \\
-0.10248^{* * *}\end{array}$ & $\begin{aligned} &(-18.09) \\
&-0.12403^{* * *}\end{aligned}$ & $\begin{array}{c}(-12.09) \\
-0.10673^{* * *}\end{array}$ \\
\hline EIzurumin & & & & & & & $\begin{array}{r}-0.10240 \\
(-9.17)\end{array}$ & $\begin{array}{r}-0.12405 \\
(-8.14)\end{array}$ & $\begin{array}{r}-0.100 / 5 \\
(-7.75)\end{array}$ \\
\hline Ağr1 & & & & & & & $-0.04155^{* *}$ & -0.05972 & $-0.05110^{* * *}$ \\
\hline Malatya & & & & & & & $\begin{array}{c}(-2.54) \\
-0.18660^{* * * *}\end{array}$ & $\begin{array}{c}(-1.57) \\
-0.17426^{* * * *}\end{array}$ & $\begin{array}{c}(-2.66) \\
-0.19208^{* * * *}\end{array}$ \\
\hline |Fialat & & & & & & & $(-17.89)$ & $(-9.14)$ & $(-14.03)$ \\
\hline Van & & & & & & & 0.00013 & $-0.07324^{* * *}$ & -0.01214 \\
\hline Gaziantep & & & & & & & $\begin{array}{c}(0.01) \\
-0.22266^{* * * *}\end{array}$ & $\begin{array}{c}(-3.86) \\
-0.17467^{* * * *}\end{array}$ & $\begin{array}{c}(-1.02) \\
-0.23579^{* * * *}\end{array}$ \\
\hline & & & & & & & $(-31.40)$ & $(-12.63)$ & $(-26.32)$ \\
\hline Şanliurfa & & & & & & & $\begin{array}{c}-0.14587^{* * * *} \\
(-2086)\end{array}$ & $\begin{array}{l}-0.07909^{* * * *} \\
(-284)\end{array}$ & $\begin{array}{c}-0.17285^{* * *} \\
(-26.82)\end{array}$ \\
\hline Mardin & & & & & & & $-0.19136^{* * * *}$ & $-0.06592^{* *}$ & $-0.23239^{* * * *}$ \\
\hline Constant & $\begin{array}{c}3.82183^{* * *} \\
(286.06)\end{array}$ & $\begin{array}{c}4.10512^{* * *} \\
(165.70)\end{array}$ & $\begin{array}{c}3.74758^{* * *} \\
(227.54)\end{array}$ & $\begin{array}{c}3.95441^{* * *} \\
(258.80)\end{array}$ & $\begin{array}{c}4.31737^{* * * *} \\
(245.66)\end{array}$ & $\begin{array}{c}3.82964^{* * *} \\
(142.61)\end{array}$ & $\begin{array}{c}(-23.09) \\
4.07552^{* * * *} \\
(407.1)\end{array}$ & $\begin{array}{c}(-2.57) \\
4.35959^{* * *}\end{array}$ & $\begin{array}{c}(-25.96) \\
3.99253^{* * *}\end{array}$ \\
\hline \multicolumn{10}{|l|}{ 990 } \\
\hline Age & $0.08135^{* * *}$ & $0.06896^{* * *}$ & $0.09765^{* * *}$ & $0.04521^{* * *}$ & $0.02704^{* * *}$ & $0.06280^{* * *}$ & $0.04467^{* * * *}$ & $0.02795^{* * * *}$ & $0.05997^{* * * *}$ \\
\hline & $(55.56)$ & $(30.43)$ & $(51.89)$ & $(38.57)$ & $(16.30)$ & $(58.48)$ & (37.88) & $(17.53)$ & $(47.07)$ \\
\hline Age2 & $-0.00102^{* * *}$ & $-0.00095^{* * *}$ & $-0.00122^{* * *}$ & $-0.00054^{* * *}$ & $-0.00034^{* * *}$ & $-0.00075^{* * *}$ & $-0.00052^{* * *}$ & $-0.00035^{* * *}$ & $-0.00070^{* * * *}$ \\
\hline & $(-51.44)$ & $(-31.44)$ & $(-48.80)$ & $(-34.02)$ & $(-14.80)$ & $(-45.34)$ & $(-31.63)$ & $(-16.99)$ & $(-35.27)$ \\
\hline Male & $\begin{array}{c}0.03707^{* * * *} \\
(7.61)\end{array}$ & & & $\begin{array}{c}0.16453^{* * *} \\
(35.31)\end{array}$ & & & $\begin{array}{c}0.16839^{* * * *} \\
(31.38)\end{array}$ & & \\
\hline Unemployed(t-1) & $0.17773^{* * *}$ & $0.25433^{* * *}$ & $-0.04662^{* * *}$ & $0.08576^{* * * *}$ & $0.04596^{* * *}$ & $0.03454^{* * *}$ & $0.05710^{* * * *}$ & $0.01879^{* * *}$ & 0.01399 \\
\hline Military (t-1) & $0.27128^{* * * *}$ & 0.00000 & $0.06269^{* * * *}$ & $0.10080^{* * *}$ & $\begin{array}{c}(1.06) \\
0.00000\end{array}$ & $0.07495^{* * *}$ & $\begin{array}{c}(10.01) \\
0.07871^{* * * *}\end{array}$ & $\begin{array}{c}(4.02) \\
0.00000\end{array}$ & $\begin{array}{c}(0.81) \\
0.06306^{z * * *}\end{array}$ \\
\hline & (24.01) & (.) & $(3.25)$ & $(13.86)$ & (.) & $(6.16)$ & $(10.52)$ & (.) & $(3.24)$ \\
\hline In school (t-1) & $\begin{array}{c}0.38455^{* * * *} \\
(35.27)\end{array}$ & $\begin{array}{c}0.42510^{* * *} \\
(35.33)\end{array}$ & $\begin{array}{c}0.16640^{* * * *} \\
(7.98)\end{array}$ & $\begin{array}{c}0.02334^{* * *} \\
(3.79)\end{array}$ & $\begin{array}{c}-0.00000 \\
(-0.00)\end{array}$ & $\begin{array}{c}-0.01055 \\
(-0.91)\end{array}$ & $\begin{array}{c}0.00789 \\
(1.12)\end{array}$ & $\begin{array}{c}-0.01067^{*} \\
(-1.73)\end{array}$ & $\begin{array}{c}-0.02599 \\
(-1.49)\end{array}$ \\
\hline Private Office & $0.17979^{* * * *}$ & $0.20812^{* * *}$ & $0.19502^{* * *}$ & 0.02082 & 0.01947 & 0.04853 & 0.02241 & -0.02640 & $0.10178^{* *}$ \\
\hline & (5.18) & (3.24) & (3.77) & $(0.81)$ & $(0.25)$ & $(1.18)$ & $(0.69)$ & $(-0.77)$ & $(2.28)$ \\
\hline Public Office & $\begin{array}{c}-0.29247^{* * *} \\
(-27.35)\end{array}$ & $\begin{array}{c}-0.24002^{* * *} \\
(-21.87)\end{array}$ & $\begin{array}{c}-0.28284^{* * *} \\
(-17.44)\end{array}$ & $\begin{array}{c}-0.14487^{* * *} \\
(-15.46)\end{array}$ & $\begin{array}{c}-0.05642^{* * *} \\
(-9.85)\end{array}$ & $\begin{array}{c}-0.21885^{* * *} \\
(-19.64)\end{array}$ & $\begin{array}{c}-0.11635^{\text {*** }} \\
(-11.18)\end{array}$ & $\begin{array}{c}-0.02433^{* * * *} \\
(-2.85)\end{array}$ & $\begin{array}{c}-0.18888^{* * * *} \\
(-17.94)\end{array}$ \\
\hline Network & $-0.14893^{* * *}$ & $-0.19030^{* * * *}$ & $-0.10917^{* * 4}$ & $-0.04847^{* * *}$ & $-0.05637^{* * *}$ & $-0.02529^{* * * *}$ & $-0.03665^{* * * *}$ & $-0.04239^{* * * *}$ & $-0.02008^{* * * *}$ \\
\hline & & $(-25.72)$ & $(-19.68)$ & $\begin{array}{l}(-14.27) \\
0.03816^{*}\end{array}$ & $(-11.54)$ & $(-4.74)$ & $(-10.66)$ & $(-12.25)$ & $(-4.86)$ \\
\hline Other & $\begin{array}{c}0.30025^{* * *} \\
(11.19)\end{array}$ & $\begin{array}{c}0.26985^{* * *} \\
(10.67)\end{array}$ & $\begin{array}{c}0.30246^{* * *} \\
(11.14)\end{array}$ & $\begin{array}{c}0.03816^{*} \\
(1.86)\end{array}$ & $\begin{array}{c}0.04146 \\
(1.08)\end{array}$ & $\begin{array}{c}0.04293 \\
(1.61)\end{array}$ & $\begin{array}{c}0.07979^{* * *} \\
(3.89)\end{array}$ & $\begin{array}{c}0.07130^{* *} \\
(2.05)\end{array}$ & $\begin{array}{c}0.07721^{* * * *} \\
(3.35)\end{array}$ \\
\hline Year-2005 & $\begin{array}{c}0.21762^{* * * *} \\
(18.43)\end{array}$ & $\begin{array}{c}0.18612^{* * *} \\
(8.49)\end{array}$ & $\begin{array}{c}0.23594^{* * *} \\
(15.68)\end{array}$ & $\begin{array}{c}0.19288^{* * *} \\
(18.59)\end{array}$ & $\begin{array}{c}0.17608^{* * *} \\
(15.64)\end{array}$ & $\begin{array}{c}0.20288^{* * *} \\
(14.53)\end{array}$ & $\begin{array}{c}0.18447^{* * *} \\
(20.03)\end{array}$ & $\begin{array}{c}0.17184^{* * *} \\
(14.07)\end{array}$ & $\begin{array}{c}0.20176^{* * *} \\
(20.77)\end{array}$ \\
\hline Year-2006 & $0.43094^{* * *}$ & $0.40879^{* * *}$ & $0.44064^{* * *}$ & $0.39660^{* * * *}$ & $0.36639^{* * * *}$ & $0.41638^{* * *}$ & $0.40335^{* * *}$ & $0.36896^{* * * *}$ & $0.42576^{* * * *}$ \\
\hline & $\begin{array}{c}(26.76) \\
064698^{* * * *}\end{array}$ & $\begin{array}{l}(18.74) \\
061.001 * * *\end{array}$ & $\begin{array}{l}(30.79) \\
067873^{* * * *}\end{array}$ & $\begin{array}{l}(32.87) \\
062176^{* * * *}\end{array}$ & $\begin{array}{l}(27.88) \\
0.57102^{* * *}\end{array}$ & $\begin{array}{c}(30.75) \\
065441^{* * *}\end{array}$ & $\begin{array}{c}(43.05) \\
0.61656^{* * * *}\end{array}$ & $\begin{array}{c}(34.27) \\
0.966^{* * * *}\end{array}$ & $(40.55)$ \\
\hline Year-2007 & $\begin{array}{c}0.64698^{* * * *} \\
(47.22)\end{array}$ & $\begin{array}{c}0.61001^{* * *} \\
(21.93)\end{array}$ & $\begin{array}{c}0.67873^{* * *} \\
(48.63)\end{array}$ & $\begin{array}{c}0.62176^{* * *} \\
(54.18)\end{array}$ & $\begin{array}{c}0.57102^{* * *} \\
(34.76)\end{array}$ & $\begin{array}{c}0.65441^{* * *} \\
(45.40)\end{array}$ & $\begin{array}{c}0.61656^{* * *} \\
(64.39)\end{array}$ & $\begin{array}{c}0.57966^{* * *} \\
(39.11)\end{array}$ & $\begin{array}{c}0.65103^{* * *} \\
(51.73)\end{array}$ \\
\hline Year-2008 & $0.89712^{* * * *}$ & $0.87592^{* * *}$ & $0.91301^{* * *}$ & $0.83833^{* * *}$ & $0.80778^{* * *}$ & $0.87501^{* * * *}$ & $0.84816^{* * *}$ & $0.79339^{* * * *}$ & $0.88338^{* * *}$ \\
\hline & $(72.17)$ & $(32.39)$ & $(73.87)$ & (102.63) & $(66.83)$ & $(76.90)$ & $(113.03)$ & $(50.55)$ & $(69.80)$ \\
\hline Year-2009 & $1.00884^{* * * *}$ & $0.97890^{* * * *}$ & $\begin{array}{l}1.03103^{* * * *} \\
(6275)\end{array}$ & $0.97747^{* * *}$ & $0.92808^{* * *}$ & $1.01908^{* * * *}$ & $0.98478^{* * * *}$ & $0.93402^{* * * *}$ & $1.02462^{* * * *}$ \\
\hline & $(64.19)$ & $(37.74)$ & $(62.75)$ & $(79.57)$ & $(94.90)$ & $(69.01)$ & $(128.46)$ & $(74.08)$ & $(98.09)$ \\
\hline Year-2010 & $1.14892^{* * * *}$ & $1.11429^{* * * *}$ & $1.17221^{* * *}$ & $1.13572^{* * *}$ & $1.09292^{* * * *}$ & $1.16793^{* * * *}$ & $1.14600^{* * *}$ & $1.10674^{* * * *}$ & $1.17698^{* * *}$ \\
\hline & $(91.95)$ & $(54.78)$ & $(72.76)$ & $(123.68)$ & $(83.80)$ & $(85.92)$ & $(110.52)$ & $(102.26)$ & (97.73) \\
\hline
\end{tabular}




\begin{tabular}{|c|c|c|c|c|c|c|c|c|c|}
\hline & Total & Female & Male & Total Education & Female Education & Male Education & Total Region & Female Region & Male Region \\
\hline Year-2011 & $\begin{array}{c}1.33435^{* * *} \\
(120.36)\end{array}$ & $\begin{array}{c}1.26679^{* * * *} \\
(62.95)\end{array}$ & $\begin{array}{c}1.38272^{* * *} \\
(117.10)\end{array}$ & $\begin{array}{l}1.28945^{* * *} \\
(121.05)\end{array}$ & $\begin{array}{c}1.22675^{* * *} \\
(101.36)\end{array}$ & $\begin{array}{l}1.34883^{* * *} \\
(92.78)\end{array}$ & $\begin{array}{c}1.29663^{* * * *} \\
(160.26)\end{array}$ & $\begin{array}{c}1.23171^{* * *} \\
(114.46)\end{array}$ & $\begin{array}{c}1.35406^{* * * *} \\
(89.45)\end{array}$ \\
\hline Year-2012 & $\begin{array}{c}1.52726^{* * * *} \\
(89.04)\end{array}$ & $\begin{array}{l}1.48051^{* * *} \\
(66.75)\end{array}$ & $\begin{array}{c}1.56765^{* * *} \\
(120.41)\end{array}$ & $\begin{array}{c}1.45783^{* * * *} \\
(163.41)\end{array}$ & $\begin{array}{c}1.40665^{* * *} \\
(113.62)\end{array}$ & $\begin{array}{l}1.50124^{* * * *} \\
(126.08)\end{array}$ & $\begin{array}{c}1.47086^{* * *} \\
(193.22)\end{array}$ & $\begin{array}{l}1.43162^{* * *} \\
(130.76)\end{array}$ & $\begin{array}{l}1.51217^{* * *} \\
(111.37)\end{array}$ \\
\hline Year-2013 & $\begin{array}{c}1.71493^{* * * *} \\
(164.99)\end{array}$ & $\begin{array}{c}1.65572^{* * * *} \\
(82.41)\end{array}$ & $\begin{array}{c}1.75470^{* * *} \\
(97.91)\end{array}$ & $\begin{array}{c}1.64401^{* * * *} \\
(178.86)\end{array}$ & $\begin{array}{l}1.57182^{* * *} \\
(160.76)\end{array}$ & $\begin{array}{c}1.71326^{* * *} \\
(162.59)\end{array}$ & $\begin{array}{l}1.65659^{* * * *} \\
(177.83)\end{array}$ & $\begin{array}{l}1.59654^{* * *} \\
(130.34)\end{array}$ & $\begin{array}{l}1.71305^{* * *} \\
(128.03)\end{array}$ \\
\hline Year-2014 & $\begin{array}{c}1.92060^{* * * *} \\
(161.88)\end{array}$ & $\begin{array}{c}1.84637^{* * * *} \\
(73.75)\end{array}$ & $\begin{array}{c}1.97178^{* * *} \\
(138.38)\end{array}$ & $\begin{array}{l}1.86337^{* * * *} \\
(255.33)\end{array}$ & $\begin{array}{c}1.76729^{* * *} \\
(152.74)\end{array}$ & $\begin{array}{c}1.93035^{* * *} \\
(132.04)\end{array}$ & $\begin{array}{l}1.86598^{* * *} \\
(229.42)\end{array}$ & $\begin{array}{c}1.78233^{* * *} \\
(179.15)\end{array}$ & $\begin{array}{c}1.92751^{* * *} \\
(122.60)\end{array}$ \\
\hline Year-2015 & $\begin{array}{l}2.07106^{* * * *} \\
(176.58)\end{array}$ & $\begin{array}{l}2.02933^{* * * *} \\
(91.46)\end{array}$ & $\begin{array}{c}2.11510^{* * * *} \\
(147.72)\end{array}$ & $\begin{array}{l}2.01463^{* * * *} \\
(215.40)\end{array}$ & $\begin{array}{l}1.94728^{* * * *} \\
(164.61)\end{array}$ & $\begin{array}{c}2.07626^{* * * *} \\
(164.08)\end{array}$ & $\begin{array}{c}2.02182^{* * *} \\
(232.88)\end{array}$ & $\begin{array}{l}1.96760^{* * * *} \\
(176.52)\end{array}$ & $\begin{array}{l}2.07548^{* * *} \\
(212.03)\end{array}$ \\
\hline Year-2016 & $\begin{array}{c}2.32924^{* * * *} \\
(188.63)\end{array}$ & $\begin{array}{l}2.28201^{* * * *} \\
(98.86)\end{array}$ & $\begin{array}{c}2.35292^{* * *} \\
(201.13)\end{array}$ & $\begin{array}{l}2.27033^{* * * *} \\
(257.84)\end{array}$ & $\begin{array}{l}2.23486^{* * *} \\
(223.85)\end{array}$ & $\begin{array}{c}2.31281^{* * * *} \\
(174.71)\end{array}$ & $\begin{array}{l}2.28152^{* * * *} \\
(299.89)\end{array}$ & $\begin{array}{l}2.26738^{* * *} \\
(246.55)\end{array}$ & $\begin{array}{c}2.31879^{* * * *} \\
(206.28)\end{array}$ \\
\hline Literate & & & & $\begin{array}{c}0.12250^{* * * *} \\
(9.54)\end{array}$ & $\begin{array}{c}0.05515^{* * * *} \\
(2.90)\end{array}$ & $\begin{array}{c}0.13095^{* * *} \\
(5.87)\end{array}$ & $\begin{array}{c}0.10449^{* * * *} \\
(7.17)\end{array}$ & $\begin{array}{c}0.07012^{* * * *} \\
(5.12)\end{array}$ & $\begin{array}{c}0.12054^{* * * *} \\
(5.82)\end{array}$ \\
\hline Primary & & & & $\begin{array}{c}0.08659^{* * *} \\
(8.73)\end{array}$ & $\begin{array}{c}0.01042 \\
(1.12)\end{array}$ & $\begin{array}{c}0.11154^{* * *} \\
(6.45)\end{array}$ & $\begin{array}{c}0.09733^{* * *} \\
(7.50)\end{array}$ & $\begin{array}{c}0.04756^{* * * *} \\
(3.84)\end{array}$ & $\begin{array}{l}0.12481^{* * *} \\
\quad(5.56)\end{array}$ \\
\hline Secondary & & & & $\begin{array}{c}0.10293^{* * *} \\
(11.73)\end{array}$ & $\begin{array}{l}0.05523^{* * *} \\
(4.12)\end{array}$ & $\begin{array}{l}0.11491^{* * *} \\
(6.50)\end{array}$ & $\begin{array}{l}0.11629^{* * *} \\
(9.04)\end{array}$ & $\begin{array}{l}0.09358^{* * *} \\
(6.92)\end{array}$ & $\begin{array}{c}0.13403^{* * *} \\
(6.07)\end{array}$ \\
\hline Highschool & & & & $\begin{array}{l}0.21931^{* * *} \\
(24.62)\end{array}$ & $\begin{array}{l}0.22208^{* * *} \\
(16.15)\end{array}$ & $\begin{array}{l}0.20467^{* * *} \\
(12.02)\end{array}$ & $\begin{array}{l}0.22997^{* * *} \\
(17.28)\end{array}$ & $\begin{array}{c}0.23799^{* * *} \\
(19.69)\end{array}$ & $\begin{array}{l}0.22191^{* * *} \\
(10.53)\end{array}$ \\
\hline Voc-Highschool & & & & $\begin{array}{l}0.24453^{* * *} \\
(23.85)\end{array}$ & $\begin{array}{c}0.26775^{* * *} \\
(19.00)\end{array}$ & $\begin{array}{l}0.21677^{* * *} \\
(12.27)\end{array}$ & $\begin{array}{l}0.26002^{* * *} \\
(19.07)\end{array}$ & $\begin{array}{l}0.30113^{* * *} \\
(20.82)\end{array}$ & $\begin{array}{c}0.23986^{* * *} \\
(13.56)\end{array}$ \\
\hline Uni \& Higher & & & & $\begin{array}{c}0.84305^{* * *} \\
(76.52)\end{array}$ & $\begin{array}{c}0.85416^{* * *} \\
(76.72)\end{array}$ & $\begin{array}{c}0.82978^{* * *} \\
(42.25)\end{array}$ & $\begin{array}{l}0.84751^{* * *} \\
(57.92)\end{array}$ & $\begin{array}{l}0.87444^{* * * *} \\
(54.08)\end{array}$ & $\begin{array}{c}0.83382^{2 * *} \\
(42.12)\end{array}$ \\
\hline Tekirdag & & & & & & & $\begin{array}{c}-0.15323^{* * *} \\
(-19.83)\end{array}$ & $\begin{array}{c}-0.16192^{* * *} \\
(-12.10)\end{array}$ & $\begin{array}{c}-0.16155^{* * *} \\
(-10.95)\end{array}$ \\
\hline Balikesir & & & & & & & $\begin{array}{c}-0.21335^{* * *} \\
(-19.75)\end{array}$ & $\begin{array}{c}-0.21581^{* * *} \\
(-12.66)\end{array}$ & $\begin{array}{c}-0.19752^{* * *} \\
(-11.44)\end{array}$ \\
\hline Izmir & & & & & & & $\begin{array}{c}-0.15110^{* * *} \\
(-21.78)\end{array}$ & $\begin{array}{c}-0.16735^{* * *} \\
(-14.50)\end{array}$ & $\begin{array}{c}-0.14869^{* * *} \\
(-21.45)\end{array}$ \\
\hline Aydin & & & & & & & $\begin{array}{c}-0.17759^{* * *} \\
(-18.33)\end{array}$ & $\begin{array}{c}-0.19160^{* * *} \\
(-18.02)\end{array}$ & $\begin{array}{c}-0.17747^{* * *} \\
(-19.73)\end{array}$ \\
\hline Manisa & & & & & & & $\begin{array}{c}-0.23718^{* * * *} \\
(-23.04)\end{array}$ & $\begin{array}{c}-0.20593^{* * *} \\
(-18.05)\end{array}$ & $\begin{array}{c}-0.26548^{* * *} \\
(-23.56)\end{array}$ \\
\hline Bursa & & & & & & & $-0.17275^{* * *}$ & $-0.17017^{* * *}$ & $-0.18261^{* * * *}$ \\
\hline Kocaeli & & & & & & & $\begin{array}{c}(-22.00) \\
-0.11508^{* * *}\end{array}$ & $\begin{array}{c}(-18.19)^{* * *} \\
-0.16801^{* * *}\end{array}$ & $-0.08950^{* * *}$ \\
\hline Ankara & & & & & & & $\begin{array}{c}-0.05375^{* * * *} \\
(-6.00)\end{array}$ & $\begin{array}{c}-0.06039^{* * * *} \\
(-3.79)\end{array}$ & $\begin{array}{c}-0.05235^{* * *} \\
(-3.70)\end{array}$ \\
\hline Konya & & & & & & & $\begin{array}{c}-0.18900^{* * * *} \\
(-22.20)\end{array}$ & $\begin{array}{c}-0.19030^{* * *} \\
(-19.63)\end{array}$ & $\begin{array}{c}-0.19721^{* * *} \\
(-1587)\end{array}$ \\
\hline Antalya & & & & & & & $-0.09100^{* * * *}$ & $\begin{array}{c}-0.12038^{* * * *} \\
(-7.84)\end{array}$ & $-0.06879^{* * *}$ \\
\hline Adana & & & & & & & $-0.25436^{* * * *}$ & $-0.25491^{* * *}$ & $-0.25701^{* * *}$ \\
\hline Hatay & & & & & & & $\begin{array}{c}(-25.91) \\
-0.19095^{* * *}\end{array}$ & $-0.25459^{* * *}$ & $-0.16367^{* * *}$ \\
\hline Kirikkale & & & & & & & $\begin{array}{c}(-20.83) \\
-0.15571^{* * *}\end{array}$ & $\begin{array}{c}(-16.94) \\
-0.18465^{* * *}\end{array}$ & $\begin{array}{c}(-12.92) \\
-0.16828^{* * * *}\end{array}$ \\
\hline & & & & & & & $(-15.45)$ & $(-12.01)$ & $(-14.29)$ \\
\hline Kayseri & & & & & & & $\begin{array}{c}-0.15783^{* * * *} \\
(-15.41)\end{array}$ & $\begin{array}{c}-0.21159^{* * * *} \\
(-13.09)\end{array}$ & $\begin{array}{c}-0.13516^{* * * *} \\
(-7.53)\end{array}$ \\
\hline
\end{tabular}




\begin{tabular}{|c|c|c|c|c|c|c|c|c|c|}
\hline & Total & Female & Male & Total Education & Female Education & Male Education & Total Region & Female Region & Male Region \\
\hline Zonguldak & & & & & & & $\begin{array}{c}-0.19062^{* * * *} \\
(-13.37)\end{array}$ & $\begin{array}{c}-0.23836^{* * *} \\
(-20.79)\end{array}$ & $\begin{array}{c}-0.17535^{* * *} \\
(-9.40)\end{array}$ \\
\hline Kastamonu & & & & & & & $\begin{array}{c}-0.17881^{* * * * *} \\
(-8.55)\end{array}$ & $\begin{array}{c}-0.19077^{* * * *} \\
(-13.37)\end{array}$ & $\begin{array}{c}-0.18875^{* * *} \\
(-10.22)\end{array}$ \\
\hline Samsun & & & & & & & $-0.15714^{* * *}$ & $-0.21683^{* * * *}$ & $-0.11551^{* * * *}$ \\
\hline Trabzon & & & & & & & $-0.10172^{* * * *}$ & $-0.19021^{* * * *}$ & $-0.07576^{* * *}$ \\
\hline & & & & & & & $(-8.63)$ & $(-15.97)$ & $(-5.55)$ \\
\hline Erzurum & & & & & & & $\begin{array}{c}-0.02604 \\
(-1.63)\end{array}$ & $\begin{array}{c}-0.05736^{* *} \\
(-2.15)\end{array}$ & $\begin{array}{c}-0.05121^{* *} \\
(-2.48)\end{array}$ \\
\hline Ağr1 & & & & & & & $0.05213^{* * *}$ & 0.01007 & $0.05570^{* *}$ \\
\hline Malatya & & & & & & & $-0.16354^{* * *}$ & $-0.18854^{* * * *}$ & $-0.16808^{* * * *}$ \\
\hline & & & & & & & $(-12.89)$ & $(-7.29)$ & $(-12.04)$ \\
\hline Van & & & & & & & $\begin{array}{c}0.06806^{* * *} \\
(7.77)\end{array}$ & $\begin{array}{c}-0.05700^{* * *} \\
(-2.58)\end{array}$ & $\begin{array}{c}0.06640^{* * * *} \\
(4.54)\end{array}$ \\
\hline Gaziantep & & & & & & & $-0.21198^{* * * *}$ & $-0.19060^{* * *}$ & $-0.23729^{* * *}$ \\
\hline Sanluurf & & & & & & & $\begin{array}{c}(-25.92) \\
-0110^{* * *}\end{array}$ & $\begin{array}{c}(-12.39) \\
-0.02612\end{array}$ & $\begin{array}{c}(-20.57) \\
-013383^{* * *}\end{array}$ \\
\hline ק्mintrá & & & & & & & $\begin{array}{r}-0.10110 \\
(-7.71)\end{array}$ & $\begin{array}{c}-0.02612 \\
(-1.35)\end{array}$ & $\begin{array}{c}-0.13383 \\
(-11.46)\end{array}$ \\
\hline Mardin & & & & & & & $-0.13526^{* * *}$ & $-0.03394^{*}$ & $-0.17961^{* * *}$ \\
\hline Constant & $\begin{array}{c}3.66695^{* * *} \\
(166.95)\end{array}$ & $\begin{array}{c}3.96809^{* * * *} \\
(97.69)\end{array}$ & $\begin{array}{c}3.59618^{* * *} \\
(114.41)\end{array}$ & $\begin{array}{c}4.01241^{* * *} \\
(215.23)\end{array}$ & $\begin{array}{c}4.43872^{* * *} \\
(143.05)\end{array}$ & $\begin{array}{c}3.86285^{* * *} \\
(177.76)\end{array}$ & $\begin{array}{c}(-9.71) \\
4.12323^{* * *} \\
(177.61)\end{array}$ & $\begin{array}{c}(-1.65) \\
4.51595^{* * *} \\
(161.72)\end{array}$ & $\begin{array}{c}(-13.47) \\
4.00785^{* * *} \\
(143.43)\end{array}$ \\
\hline Observations & 145138 & 49254 & 95884 & 145138 & 49254 & 95884 & 145138 & 49254 & 95884 \\
\hline
\end{tabular}

Note: $t$ statistics are in parentheses; $* p<0.1, * * p<0.05, * * * p<0.01$. 